\title{
REVIEW
}

\section{Effects of climate change on Mediterranean marine ecosystems: the case of the Catalan Sea}

\author{
Eva Calvo ${ }^{1, *}$, Rafel Simó ${ }^{1}$, Rafel Coma ${ }^{2}$, Marta Ribes ${ }^{1}$, Josep Pascual ${ }^{3}$, \\ Anna Sabatés ${ }^{1}$, Josep M. Gili ${ }^{1}$, Carles Pelejero ${ }^{1,4}$ \\ ${ }^{1}$ Institut de Ciències del Mar, CSIC, 08003 Barcelona, Spain \\ ${ }^{2}$ Centre d'Estudis Avançats de Blanes, CSIC, 17300 Blanes, Spain \\ ${ }^{3}$ Estació Meteorològica de l'Estartit, Girona, Spain \\ ${ }^{4}$ Institució Catalana de Recerca i Estudis Avançats (ICREA), 08010 Barcelona, Spain
}

\begin{abstract}
The Catalan Sea, located between the eastern Iberian coast and the Balearic Islands, is a representative portion of the western Mediterranean basin and provides a valuable case study for climate change effects on Mediterranean ecosystems. Global warming is reflected regionally by a rise in sea level over the last century, an increase in surface temperature of around $1.1^{\circ} \mathrm{C}$ in the last $35 \mathrm{yr}$, a progressive salinisation of intermediate and deep waters and a strengthening of the stratification. A likely scenario of what we can expect in the Mediterranean Sea is a considerable decrease in rainfall and wind, warmer surface waters and a prolonged stratification period. The effects on Mediterranean ecosystems are evident in: (1) a meridionalisation of the algal, invertebrate and vertebrate species, which favours the more thermophilic species over the temperate species; (2) mass mortality events of sessile invertebrates of the coralligenous communities owing to anomalous warm waters during the period when food is scarce; (3) increases in the smallest phytoplankton due to the prolongation of the water stratification period; (4) proliferation of gelatinous carnivores, including jellyfish, due to the temperature rise and the lack of rainfall; (5) a faster acidification of seawater, compared with the global oceans, accompanied by a decrease in the capacity to absorb atmospheric $\mathrm{CO}_{2}$. In order to anticipate and mitigate these predicted changes, we recommend investing in research and observation, conserving areas that serve as indicators of climate change and reducing other anthropogenic pressures such as habitat destruction, overfishing or pollution, which may act synergistically to accelerate these changes.
\end{abstract}

KEY WORDS: Climate change $\cdot$ Marine ecosystems $\cdot$ Catalan Sea $\cdot$ Mediterranean Sea $\cdot$ Time series

\section{VULNERABILITY OF MEDITERRANEAN MARINE ECOSYSTEMS TO CLIMATE CHANGE}

The effects of climate change associated with human activity are starting to be detected in marine ecosystems of all the world's oceans (HoeghGuldberg \& Bruno 2010). The wide range of processes that are affected by climate change (e.g. meteorological, chemical, biological), however, make it very difficult to predict the magnitude and rate of its effects. Only an extensive knowledge of how the system operates will allow us to understand, interpret and predict the consequences of climate change. However, there is still very little information available on marine ecosystems, far less than there is on land ecosystems, which is mainly due to the obvious difficulties involved in studying the sea.

Several distinctive features make the Mediterranean Sea particularly sensitive to climate change. The Mediterranean Sea has only a narrow connec- 
tion with the Atlantic Ocean through the Strait of Gibraltar, an artificial connection with the Red Sea through the Suez Canal and a connection with the Black Sea through the Bosphorus Strait. The hot dry summers and scarcity of river inputs make the Mediterranean Sea a concentration basin. During winter, the intense cooling and evaporation of Atlantic surface water increase its density, which causes this water to sink in the northern parts of both the western and eastern Mediterranean basins. In the eastern basin, the formation of Levantine Intermediate Water (at $\sim 300$ to $400 \mathrm{~m}$ ) plays an important role in the functioning of the whole Mediterranean Sea, as it is involved in the formation of deep waters in the Aegean Sea, the Adriatic Sea, the Tyrrhenian Sea and the Gulf of Lion (Millot \& Taupier-Letage 2005). The small size of the Mediterranean Sea also suggests that the impact and rate of climate change will be large and rapid. The average water depth is around $1500 \mathrm{~m}$, and the renewal rate of deep water is relatively fast, between 15 and 50 yr (Bethoux et al. 2002, 2005), compared with that of the world's oceans (from centuries to millennia for the North Atlantic and world oceans, respectively, Broecker 1979, 1980). Heat and $\mathrm{CO}_{2}$ penetration is therefore very rapid (Rixen et al. 2005, Touratier \& Goyet 2009), and the effects of these changes on marine organisms may become apparent rather quickly.

Another characteristic of the Mediterranean Sea is its oligotrophy, i.e. its very low availability of macronutrients (nitrate, phosphate, silicate) in the surface waters. This is because the Mediterranean Sea receives Atlantic surface waters (poor in nutrients) through the Strait of Gibraltar, while it exports, through this strait, deep Mediterranean water rich in remineralized nutrients. This makes the Mediterranean Sea a nutrientpoor system with limited productivity. Within this context of oligotrophy, the mesoscale phenomena (fronts and divergences) of the western basin lead to considerable regional fertilisation. The degree of oligotrophy gradually increases from the western to the eastern basin, comparable with the productivity gradient, which is 3.3 times lower in the eastern basin (Krom et al. 1991, Turley et al. 2000). These differences in productivity lead to varying diversity and quantity in fishery production and the biomass of benthic organisms (Danovaro et al. 1999).

The Mediterranean Sea also contains high biological diversity. Although it occupies only $0.82 \%$ of the global ocean surface, it contains $6.3 \%$ of all described marine macrophyte and metazoan species (Coll et al. 2010). Within the Mediterranean Sea, $67 \%$ of the species are found in the western basin.
Currently, the mean percentage of native species is $20.2 \%$. The highest proportions of endemism are found in sponges (48\%), ascidians (35\%), echinoderms $(23 \%)$, bryozoans (23\%), macrophytobenthic species $(22 \%)$ and fishes $(12 \%)$. Changes in climate exert a central role on marine species (Hawkins et al. 2003) because they cause direct effects on the organisms and their biotic interactions. Furthermore, the indications for a rapid rate of change in an area with a very high proportion of endemic species (20\%) suggest that the potential impact of climate change on the overall diversity of Mediterranean ecosystems could be high. Mediterranean sessile invertebrates may be among the most affected because many of them exhibit limited dispersal abilities (Duran et al. 2004, Blanquer \& Uriz 2010, Ledoux et al. 2010, Mokhtar-Jamaï et al. 2011). Mobile taxa such as fishes may be less affected because, although a relatively high degree of population structure has also been observed in some littoral fish species (CarrerasCarbonell et al. 2006), many display differentiation at distances of hundreds to thousands of kilometers and in relation to oceanographic fronts (Patarnello et al. 2007, Galarza et al. 2009). However, risk of extinction has been identified in motile species dwelling in highly fragmented habitats (Lejeusne \& Chevaldonné 2006).

At the same time, large scale climatic variability is one of the most determinant factors of the availability of resources for marine ecosystems. In the Mediterranean Sea, the interannual temperature, wind patterns and rainfall regimes are affected by the Atlantic climate, which can be represented by a recurrent pattern of climate variability known as the North Atlantic Oscillation (NAO). Although the NAO index has been used widely in Europe, other regional indices have been developed for the Mediterranean given that the NAO only weakly explains the climate variability over this sea. The Mediterranean Oscillation (MO) relates to the difference in pressures between the North Atlantic Ocean and the southeastern Mediterranean Sea (Supić et al. 2004) and the Western Mediterranean Oscillation (WeMO) is defined from the difference in pressures between San Fernando (south of Spain) and Padua, Italy (Martin-Vide \& Lopez-Bustins 2006). The WeMO index explains the rainfall events in autumn and winter (López-Bustins et al. 2008) better than does the NAO. As there are few time series of data that are long enough, the connections observed between ecosystem dynamics and medium-term climate variability are the best indicators for understanding the responses to global warming at larger scales. 
Climate change is by no means the only cause of transformation in Mediterranean coastal ecosystems. There are many intense anthropogenic pressures: overfishing, habitat destruction, increased abundance of alien species, alteration of rivers inflow and pollution (Ballesteros 2006, Klein \& Verlaque 2008, Coma et al. 2011). At present, habitat destruction is considered the main threat for a wide variety of taxonomic groups in the Mediterranean. However, climate change is predicted to become progressively more important (Ballesteros 2006, Coll et al. 2010) due to the inertia of the phenomenon and the risk of exceeding several thresholds (Rockström et al. 2009). Potential synergies with these additional stressors are still largely unknown.

In the present study, we focus on the Catalan Sea (northwestern Mediterranean), defined by the eastern Iberian coast north of Cape La Nau and the Balearic Islands (Fig. 1). Whilst most of the Mediterranean Sea is oligotrophic, this is a relatively productive area (Estrada \& Margalef 1988). The Catalan Sea presents a cyclonic circulation with a permanent southwestward current, the Northern Current (also known as the Liguro-Provençal-Catalan Current), which flows from the Ligurian Sea (off northwest Italy) to the Catalan Sea and follows the continental slope. In the Channel of Ibiza, the Northern Current splits and one branch flows eastward along the Balearic Islands (Castellón et al. 1990) forming the Balearic front that separates the central waters of the Catalan Sea from modified Atlantic waters (Font et al. 1988).

In the following sections we first describe the most characteristic trends in the evolution of particular marine physicochemical variables and discuss the existence of significant changes in recent decades and their relationship to global climate change. We

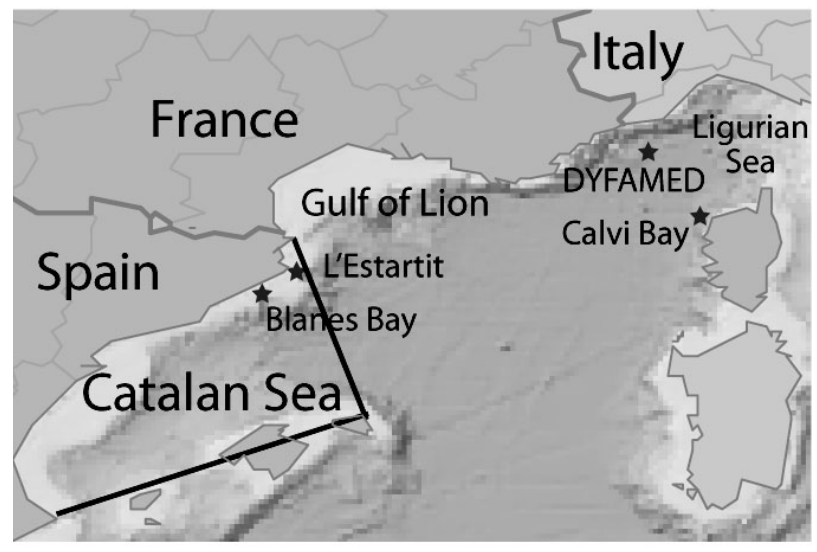

Fig. 1. Western Mediterranean Sea. Stars: oceanographic stations then select some communities and ecosystems that we consider are most representative or have the largest ecological, social and economic impact in the area of study. For each of these systems, we first present the evidence of changes in them that have occurred as a result of climate change, and then highlight the most likely future trends for organisms in these sytems in the Catalan Sea.

\section{THE GEOPHYSICAL ENVIRONMENT: IS THERE EVIDENCE OF CHANGE?}

To detect changes in the marine environment and be able to quantify their magnitude, it is necessary to have time series of key physicochemical parameters (e.g. temperature, salinity). Only then, by analysing statistically the variability over time, are we able to provide evidence for the existence of changes. Although there is a considerable network of meteorological stations on the land, comparatively little data exist for seas and oceans, which is mainly due to logistical difficulties in establishing a similar network in this environment. In the following section, we briefly recapitulate the evolution of seawater temperature, sea level, salinity, stability of the water column, seawater acidification and marine currents as well as wave and storm frequency in the Catalan Sea (see also Table 1).

\subsection{Seawater temperature}

On a global scale, as stated in the latest report of the Intergovernmental Panel on Climate Change (IPCC), ocean surface temperatures have increased, on average, by around $0.7^{\circ} \mathrm{C}$ since the beginning of the 20th century (Trenberth et al. 2007). Climate model projections for the 21 st century indicate even larger increases.

Time series data on the coastal Catalan Sea have been gathered since 1969, and without interruptions since 1974 at L'Estartit. 'L'Estartit station', which is over $90 \mathrm{~m}$ deep, is located $4 \mathrm{~km}$ from the harbour of L'Estartit, Girona, Spain, and $1.7 \mathrm{~km}$ east of the Medes Islands $\left(42^{\circ} 03^{\prime} \mathrm{N}, 3^{\circ} 15^{\prime} 15^{\prime \prime} \mathrm{E}\right.$; Fig. 1). At this site, sea temperature is measured weekly at several depths from the surface to $80 \mathrm{~m}$. Measurement of salinity and sea level, among other variables, commenced more recently (Salat \& Pascual 2002, 2006). This valuable time series from L'Estartit station shows clear intra- and interannual variability of several variables. Over the past $35 \mathrm{yr}$, a trend of increas- 


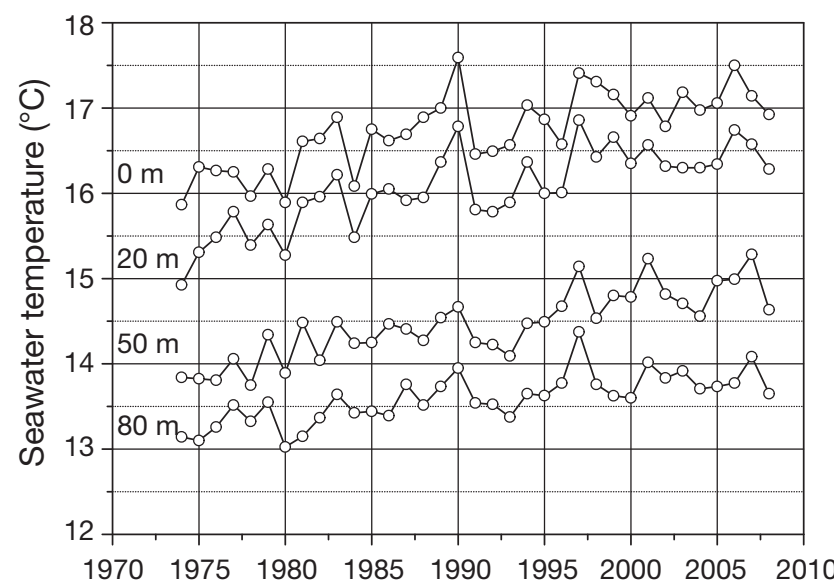

Fig. 2. Evolution over time of the mean annual sea temperatures at L'Estartit station from 1974 to 2008. From top to bottom of graph curves represent $0,20,50$ and $80 \mathrm{~m}$ depth, respectively

ing water temperature can be seen very clearly at all depths studied (Fig. 2, Table 1).

Other datasets also depict this increasing trend in temperature over the last decades. For example, climatological analyses of temperature data from the Mediterranean show an increase of around $0.5^{\circ} \mathrm{C}$ in the first $150 \mathrm{~m}$ of the water column between 1985 and 2000 (Rixen et al. 2005). At l'Estartit station, temperatures have increased around $1.1^{\circ} \mathrm{C}$ in the uppermost waters $(0$ to $50 \mathrm{~m})$ and around $0.7^{\circ} \mathrm{C}$ at $80 \mathrm{~m}$ over the last 35 yr (Figs. $2 \& 3$, Table 1), which is a similar rate to that inferred from satellite observations between 1985 and 2006 for the western Mediterranean $\left(0.03^{\circ} \mathrm{C} \mathrm{yr}^{-1}\right.$, Nykjaer 2009). The change in temperature in the northwestern Mediterranean Sea in the last decades seems to be more pronounced than the temperature increase in the oceans on a global scale. A recent compilation of temperature time series from the western Mediterranean Sea, which also includes L'Estartit station, reveals a consistent warming pattern over the last $40 \mathrm{yr}$ at a very similar increasing rate (Vargas-Yáñez et al. 2010).

As we describe in the following sections, the temperature increases are critical for many species and marine ecosystems (Table A1 in the Appendix) and lead to, for example, changes in the biogeography of native species, incorporations of new species, mass mortality events in fragile ecosystems and changes in the ecosystem's metabolism and services.

\subsection{Sea level}

On a global scale, the sea level increased by approximately 1.7 to $1.8 \mathrm{~mm} \mathrm{yr}^{-1}$ between 1961 and 2003 (Bindoff et al. 2007) and by $3.3 \mathrm{~mm} \mathrm{yr}^{-1}$ between 1993 and 2007 (Cazenave \& Llovel 2010). According to the fourth IPCC report, climate model projections indicate similar or greater increases leading to a rise in sea level of 0.18 to $0.59 \mathrm{~m}$ in the period between 1980-1999 and 2090-2099 (Meehl et al. 2007). However, this value may actually be a lower limit as the IPCC AR4 projections do not consider certain instabilities of continental ice associated with coastal glaciers. Recent studies that take these instabilities into account suggest that there will be sea level rises of 0.5 to $1.2 \mathrm{~m}$ by the end of this century (Rahmstorf 2007, Cazenave \& Llovel 2010).

Table 1. Evidence of change on the geophysical environment at selected locations in the Mediterranean Sea. (-) Data not available

\begin{tabular}{|c|c|c|c|c|c|c|}
\hline Geophysical variable & Location & Time period & Depth & Change & $\begin{array}{l}\text { Mean rate of } \\
\text { change }\left(\mathrm{yr}^{-1}\right)\end{array}$ & Reference \\
\hline Seawater temperature & $\begin{array}{l}\text { Western } \\
\text { Mediterranean } \\
\text { L'Estartit } \\
\text { Western } \\
\text { Mediterranean }\end{array}$ & $\begin{array}{l}1950-2000 \\
1985-2000 \\
1974-2008 \\
1985-2006\end{array}$ & $\begin{array}{c}\text { Surface-150 m } \\
\text { Surface-150 m } \\
\text { Surface-50 m } \\
80 \mathrm{~m} \\
\text { Surface }\end{array}$ & $\begin{array}{l}+0.3^{\circ} \mathrm{C} \\
+0.5^{\circ} \mathrm{C} \\
+1.1^{\circ} \mathrm{C} \\
+0.7^{\circ} \mathrm{C} \\
+0.6^{\circ} \mathrm{C}\end{array}$ & $\begin{array}{l}+0.006^{\circ} \mathrm{C} \\
+0.033^{\circ} \mathrm{C} \\
+0.032^{\circ} \mathrm{C} \\
+0.021^{\circ} \mathrm{C} \\
+0.029^{\circ} \mathrm{C}\end{array}$ & $\begin{array}{l}\text { Rixen et al. (2005) } \\
\text { Rixen et al. (2005) } \\
\text { Present study } \\
\text { Present study } \\
\text { Nykjaer (2009) }\end{array}$ \\
\hline Sea level & L'Estartit & 1990-2009 & Surface & $+6.5 \mathrm{~cm}$ & $+3.4 \mathrm{~mm}$ & $\begin{array}{l}\text { Vargas-Yáñez et al } \\
\text { (2008); present } \\
\text { study }\end{array}$ \\
\hline Salinity & $\begin{array}{l}\text { Western } \\
\text { Mediterranean }\end{array}$ & $1950-2000$ & $\begin{array}{l}\text { Surface- } \\
\text { bottom }\end{array}$ & +0.035 to $0.04 \mathrm{psu}$ & $0.0008 \mathrm{psu}$ & Rixen et al. (2005) \\
\hline Stability of the water column ${ }^{\mathrm{a}}$ & L'Estartit & $1974-2006$ & Surface-80 m & from 75 to $164 \mathrm{~d}$ & $+1.25 \mathrm{~d}$ & Coma et al. (2009) \\
\hline Acidification & $\begin{array}{l}\text { Western } \\
\text { Mediterranean }\end{array}$ & $\begin{array}{l}\text { Preindustrial } \\
\quad \text { to } 2001\end{array}$ & $\begin{array}{l}\text { Surface- } \\
\text { bottom }\end{array}$ & $\begin{array}{c}-0.14 \text { to } \\
-0.1 \mathrm{pH} \text { units }\end{array}$ & - & $\begin{array}{l}\text { Touratier \& Goyet } \\
\text { (2011) }\end{array}$ \\
\hline $\begin{array}{l}\text { Currents, waves and storm } \\
\text { frequency }\end{array}$ & Catalan Sea & $1984-2007$ & - & $\begin{array}{l}\text { Limited or in- } \\
\text { conclusive data }\end{array}$ & - & $\begin{array}{l}\text { Sánchez-Arcilla et } \\
\text { al. (2008) }\end{array}$ \\
\hline
\end{tabular}




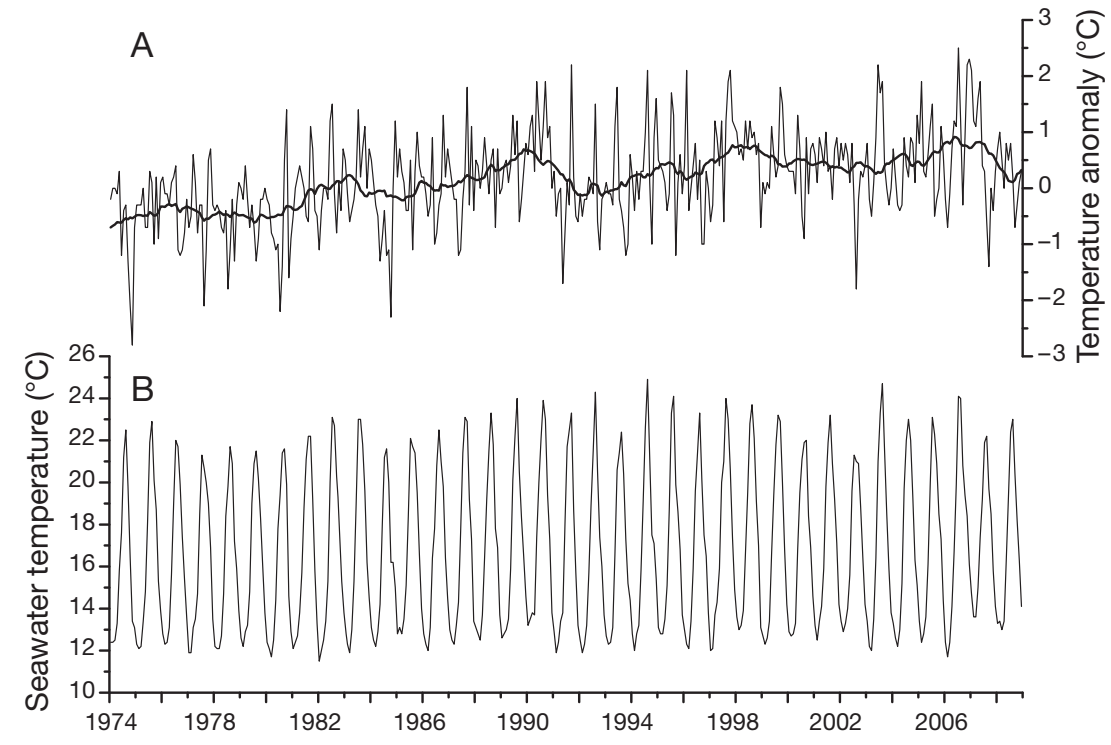

Fig. 3. Instrument records of the sea surface temperature at L'Estartit station for the period from 1974 to 2008. (A) Temperature anomalies calculated according to the difference between each monthly mean of the time series and the climatological monthly mean calculated for the entire period. The thicker line represents the data smoothed with a 24 mo moving average. (B) Monthly mean

The rise in global sea level is mainly due to the thermal expansion of water because of warming and increases in water mass due to continental ice melting. However, at a regional scale the atmospheric pressure plays a very important role: high pressures make the sea level fall and low pressures allow it rise (Gomis et al. 2008). The contribution of atmospheric pressure may account for 20 to $50 \%$ of the yearly sea level variability (Marcos \& Tsimplis 2008). In the Mediterranean Sea, the interannual variation in the atmospheric pressure is influenced by the NAO, which has effects on the sea level in the Mediterranean on a decadal scale (Tsimplis \& Josey 2001). A more recent investigation has shown that there is also a large correlation between the variations in sea level in the Mediterranean and the MO (Gomis et al. 2008).

Reconstructions based on archaeological evidence show that the level of the Mediterranean Sea has remained roughly the same over the last $2000 \mathrm{yr}$, and only began to rise significantly in the last $100 \mathrm{yr}$ (Lambeck et al. 2004, Sivan et al. 2004). This change coincides with the increase in temperature associated with global climate change.

The sea level values registered at the L'Estartit harbour since 1990 show an increase of $3.4 \mathrm{~mm} \mathrm{yr}^{-1}$ since 1990 (Fig. 4, see also Vargas-Yáñez et al. 2008). It seems, however, that the Mediterranean Sea level decreased from 1950 to 1990, probably as a result of a prolonged increase in atmospheric pressure (Tsimplis \& Josey 2001, Vargas-Yáñez et al. 2007).

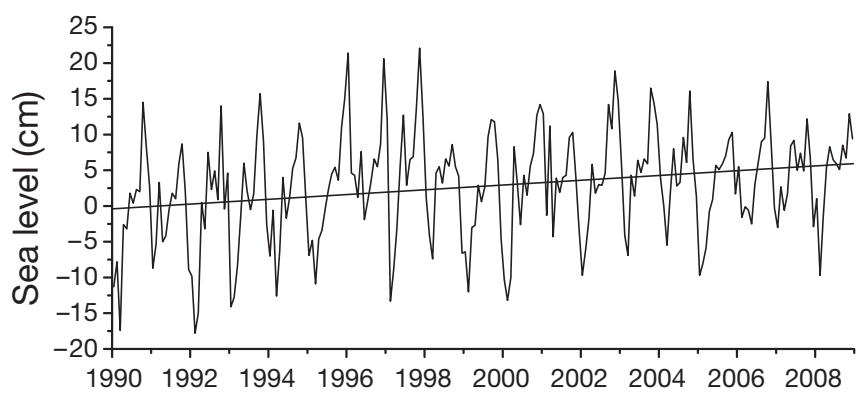

Fig. 4. Instrumental records of sea level at the L'Estartit port for the period from 1990 to 2008. The high resolution curve represents monthly means, and the straight line corresponds to the linear regression, which shows the increasing trend during this period
The sea level record from L'Estartit station, together with that from Sete and Nice, is consistent with the long-term record from nearby Marseille, which has data going back to 1885 (Marcos \& Tsimplis 2008). However, this record shows some discrepancies with those from the ports of Valencia and Barcelona since 1992 (Mosso et al. 2009). An assessment of the quality of these and other tide-gauge records from the Mediterranean indicates some inconsistencies in the record from Valencia, while the record from Barcelona, besides reflecting the more general trend of the area, also records changes in local conditions (Marcos \& Tsimplis 2008).

\subsection{Salinity}

Some studies point to a recent worldwide decrease in the salinity of the oceans (Antonov et al. 2002). However, these estimations, which are based on a limited number of observations, contain important uncertainties (Bindoff et al. 2007). In the Mediterranean Sea, the present evidence suggests the opposite trend: that is, the gradual salinisation of the water, especially in the intermediate and deep layers (more than 150 m deep) (Rixen et al. 2005, Vargas-Yáñez et al. 2010). This increased salinity seems to be related to the general decrease in rainfall and increase in evaporation in the Mediterranean area, and to the 
decrease in river flow to the sea due to the construction of dams and reservoirs (Vargas-Yáñez et al. 2007).

Changes in salinity can be critical for the circulation of ocean currents and the stability of the water column, and therefore the nutrient contribution from the deep layers to the photic zone. Such changes can disturb the structure of the communities of planktonic primary producers and the trophic chains that feed on them (e.g. Learmonth et al. 2006).

\subsection{Stability of the water column: vertical mixing and stratification}

On a global scale, climate model predictions indicate a progressive stratification of the water column (Sarmiento et al. 1998). At low latitudes, this is due to the increase in sea water temperature, which is more pronounced at the surface than in deeper layers. At high latitudes, however, it seems that the intensification of the water stratification is more related to the increase in rainfall. Both processes increase the floatability of the surface waters, stabilise the water column and make it difficult for surface waters (richer in oxygen but poorer in nutrients) and deep waters (the opposite) to mix vertically. These changes have increased the size of the oligotrophic areas of the Pacific and Atlantic oceans by 15\% from 1998 to 2006 (Polovina et al. 2008), which probably has a relationship with the recently reported decline in phytoplanktonic productivity over the past century (Boyce et al. 2010).

In the Catalan Sea, a recent study shows how stratification has intensified over the last decades (Coma et al. 2009). The data from L'Estartit station indicate that the difference between the surface and deep water temperatures has increased over the last $30 \mathrm{yr}$ (Fig. 5A). In the Catalan Sea, the water column goes through 2 very different periods: a period of thermal homogeny from December/January to March during which the water column is mixed, and a stratification period from April to November/December during which a large vertical gradient of temperature and density is established (Fig. 6). Analysis of the data from the L'Estartit station time series also shows how the stratification period has lengthened over recent decades (Coma et al. 2009). The length of the stratification period (here defined as the period in which the water temperature at $20 \mathrm{~m}$ is over $18^{\circ} \mathrm{C}$ ) increased from 75 to 164 d between 1974 and 2006 with a trend of $1.25 \mathrm{~d} \mathrm{yr}^{-1}$ (Fig. 5B). This phenomenon is not related to an increase in the freshwater inflows to the sea but to the increase in temperature (see Section 2.1).
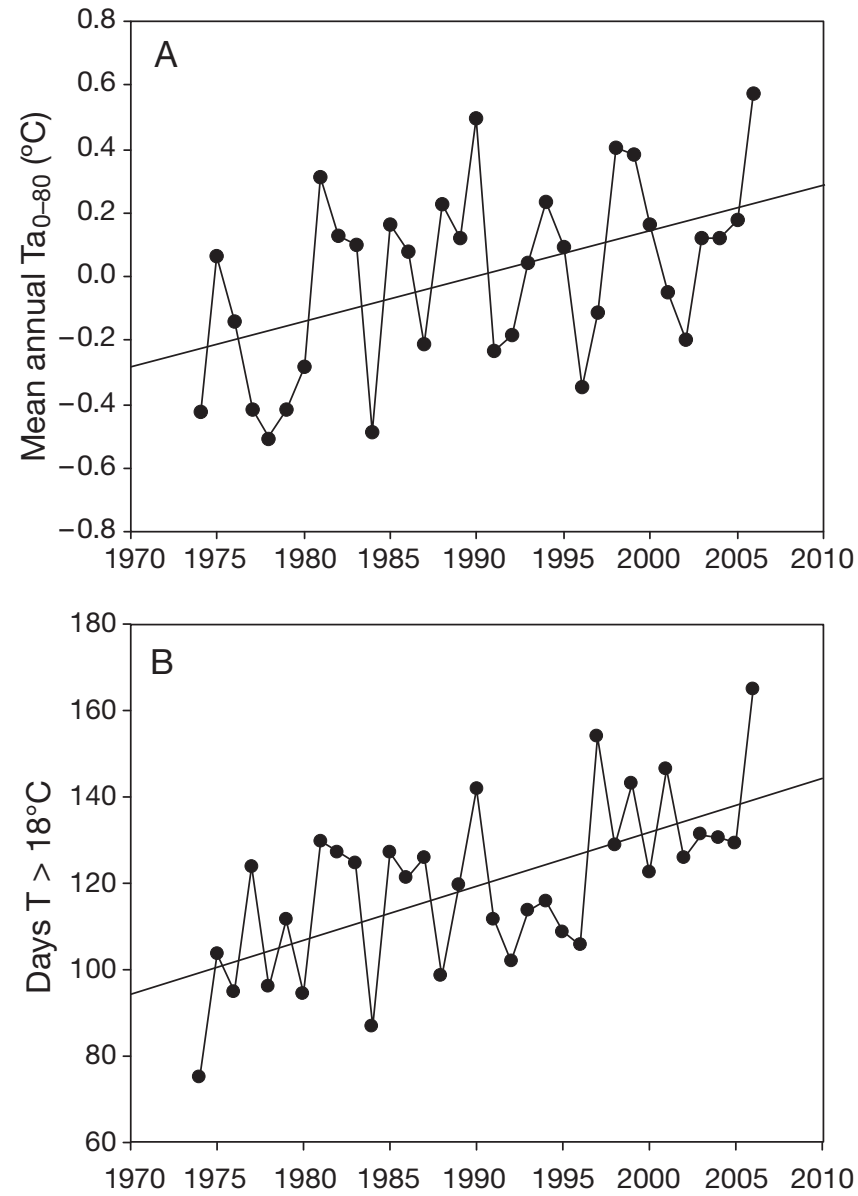

Fig. 5. Trends calculated with the temperature database from the L'Estartit time series for the period from 1974 to 2006 of: (A) the difference in seawater temperature between the surface and $80 \mathrm{~m}$ depth $\left(\mathrm{Ta}_{0-80}\right.$, calculated as the anomaly between the difference observed and the mean difference of the entire period); (B) the number of days in each year in which the temperature at $20 \mathrm{~m}$ was higher than $18^{\circ} \mathrm{C}$, which characterises the water column stratification. Figure is adapted from Coma et al. (2009)

\subsection{Acidification of the oceans: the twin of global warming}

Together with global warming, the increase in atmospheric $\mathrm{CO}_{2}$ due to anthropogenic activities is causing a progressive acidification of Earth's seas and oceans owing to the continued oceanic absorption of $\mathrm{CO}_{2}$. As soon as the $\mathrm{CO}_{2}$ molecules enter the sea, they participate in a series of chemical equilibria. This translates into (1) an increase in the concentration of hydrogen ions and therefore a decrease in $\mathrm{pH}$, and (2) a decrease in the concentration of carbonate ions, which are the basic components that calcifying organisms, such as corals, mussels, coccolithophores and pteropods, use to build their skeleton 


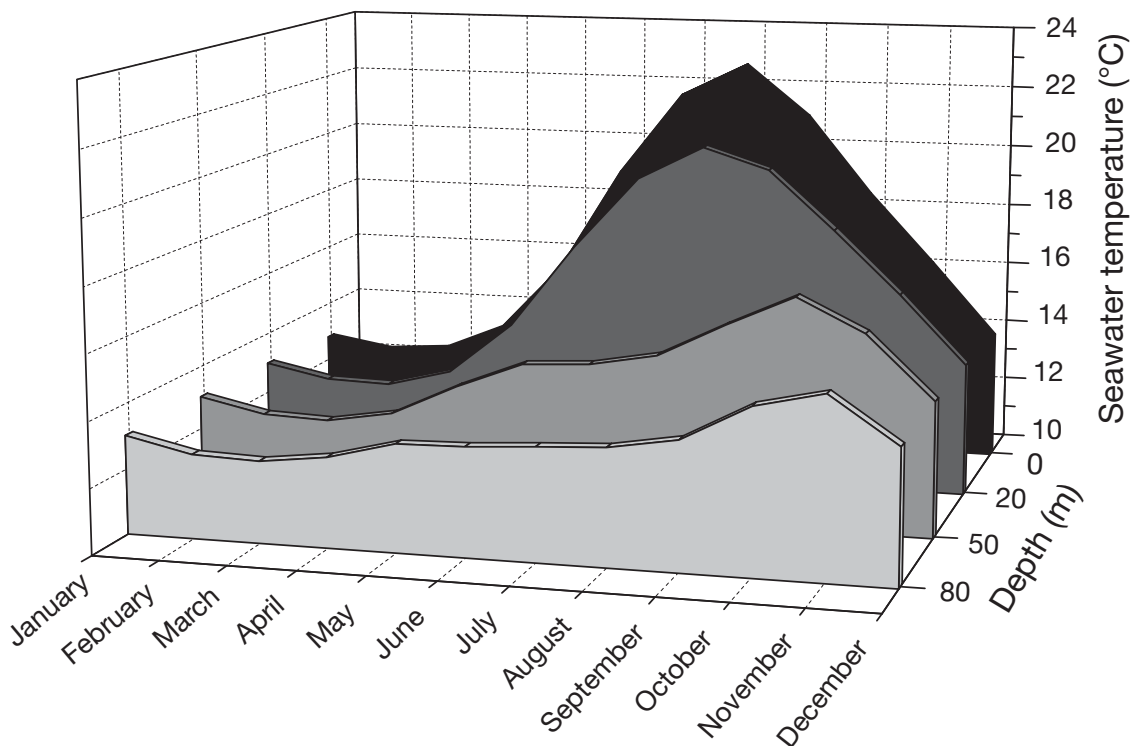

Fig. 6. Annual cycle of monthly mean seawater temperatures at L'Estartit station at 4 different depths (surface and 20,50 and $80 \mathrm{~m}$ ) for the period from 1974 to 2008

or structure. These organisms are thus expected to be affected by acidification, as this change would probably impair their growth. The changes in the chemistry of seawater due to dissolved $\mathrm{CO}_{2}$ generated by anthropogenic activities are large enough to affect other chemical, biological and gas exchange processes. The possible repercussions of the gradual acidification of seas and oceans span from the effects on individual organisms to those on ecosystems and biogeochemical cycles (see reviews in Fabry et al. 2008, Guinotte \& Fabry 2008, and Pelejero et al. 2010).

The oceanic $\mathrm{pH}$ is calculated to have already decreased an average of 0.1 units (a $30 \%$ increase in the proton concentration) relative to preindustrial levels (Raven et al. 2005). The projections of the changes in $\mathrm{pH}$ depend on the $\mathrm{CO}_{2}$ that humans emit to the atmosphere and the time they take to do so (Zeebe et al. 2008). By the end of the 21st century the predicted decrease in $\mathrm{pH}$ could be around 0.3 or 0.4 units (Steinacher et al. 2009). Paleoceanographic studies show that changes of this magnitude are unprecedented in at least the last 40 million yr (Pelejero et al. 2010).

The Mediterranean Sea has certain characteristics that make it especially sensitive and vulnerable to changes in atmospheric $\mathrm{CO}_{2}$ and gradual acidification. The residence time of the Mediterranean deep waters (from 15 to $50 \mathrm{yr}$ in the AlgeroProvencal and eastern basins, respectively, Bethoux et al. 2002, 2005) is very short in comparison with the Earth's oceans (Broecker 1979, 1980). This means that the penetration of anthropogenic $\mathrm{CO}_{2}$, which could take from centuries to millennia in the Earth's oceans depending on the region and depth, is much faster in the Mediterranean, resulting in earlier changes. Furthermore, the Mediterranean Sea is saltier and more alkaline than the world's oceans and therefore has a greater capacity to absorb $\mathrm{CO}_{2}$. A recent study that quantified the variations in the amount of anthropogenic carbon that has entered the Mediterranean during the last decade (Touratier \& Goyet 2009) showed significantly higher $\mathrm{CO}_{2}$ penetration levels than those found for the North Atlantic Ocean (Vázquez-Rodríguez et al. 2009). These results suggest that the absorption of $\mathrm{CO}_{2}$ in the Mediterranean Sea, and therefore the acidification of its waters, is occurring more quickly than in the North Atlantic, where the highest vertically integrated concentrations of anthropogenic $\mathrm{CO}_{2}$ are found (Sabine et al. 2004). Recently, a first estimation of seawater acidification in the Mediterranean Sea identified a $\mathrm{pH}$ decrease of up to 0.14 units in the western Mediterranean Sea since preindustrial times (Touratier \& Goyet 2011), which is of higher magnitude than the global surface ocean decrease of $\sim 0.1 \mathrm{pH}$ units over this time period. A recent report has also listed fairly exhaustively the possible repercussions of the acidification of the Mediterranean Sea (CIESM 2008b), although research in this area has just started.

\subsection{Marine currents, waves and storm frequency}

According to the last IPCC report, the frequency of extreme events (heat waves, droughts, floods, hurricanes) on a global scale has increased in recent decades (Trenberth et al. 2007) and is likely to further increase in the future (Meehl et al. 2007). An atmosphere with more carbon dioxide is-due to its warming characteristics - a more energetic atmosphere that has a greater capacity to store water vapour and a higher probability of developing extreme weather. With global warming, the energy of seas and oceans has also increased, which has been related to the increase in the length and intensity of tropical storms and hurricanes recorded since the 1970s (Trenberth et al. 2007). Models predict nearly a doubling of the frequency of force 4 or 5 hurricanes by the end of this century (Bender et al. 2010). 
In theory, this intensification of extreme events should also occur in the Mediterranean region, which would translate into more sea storms and intense wave episodes accompanied by the intensification of winds. The limited data from the few available time series, however, do not allow us to discern clear trends in this aspect, even though there have been several severe storm events in the northwestern Mediterranean Sea during the last decades (SánchezArcilla et al. 2008). Curiously, the future projections made so far suggest an easing of storms (Lionello et al. 2008); however, the time series of instrumental wave measurements, all less than 25 yr in length, make it difficult to predict extreme phenomena related to marine dynamics (Sánchez-Arcilla et al. 2008). Nevertheless, an increase in heat waves and droughts (Beniston et al. 2007) as well as an increase in extreme rainfall (López-Moreno \& Beniston 2009) seem to be predictable.

Changes in storm intensity and wave events could affect the marine ecosystems associated with sandy and rocky bottoms, which are often physically damaged by wave action, particularly during prolonged episodes of easterly winds, locally known as llevantades. These events also have an effect over the pelagic ecosystem, which is greatly influenced by external inputs of kinetic energy (Guadayol et al. 2009).

Climate change could also alter the marine circulation patterns of the Mediterranean Sea, which are determined by changes in water density more than by wind effects (Font 1990). The changes in salinity and temperature mentioned previously could therefore lead to alterations in marine currents. Although important changes in the dynamics of marine currents have been described, especially deep currents (see the revision in CIESM 2009), there are still no specific predictions on the changes we can expect for the future. For marine ecosystems, changes in the marine currents could affect, for example, the migration movements of marine species that rely on being carried by the current (CIESM 2009).

\section{EFFECTS ON MARINE ORGANISMS}

\subsection{Planktonic primary producers and heterotrophs}

Plankton up to $0.2 \mathrm{~mm}$ in size comprise most of the biomass and diversity, carry out virtually all marine primary production and are the base of the food web of the pelagic ecosystem. In addition, they act as a vehicle to cycle the main elements and are responsible for most of the exchanges of materials between the sea and the atmosphere (Falkowski et al. 1998). It is not possible to understand the effects of climate change on the pelagic ecosystem without understanding its effects on planktonic organisms, both individually and collectively. Unlike the organisms with more collective biomass on land, which have relatively long lives and are closely linked to their place on the land, planktonic organisms have a more ephemeral dynamic as they are located in a moving, changing environment. This is especially relevant for primary producers; the phytoplankton depend on the hydrography, mainly the stability of the water column and how it fluctuates over time (Margalef 1978). These factors not only determine the potential production and biomass, they also determine the size structure, the taxonomic composition, the biogeochemical dynamic and functions of the phytoplankton community. From here, the trophic webs are structured through bacteria that decompose organic material, bacterivorous, herbivorous and carnivorous protists and filter feeders or preying pluricellular organisms.

The impacts of climate on plankton can be direct, such as through the effects of temperature and solar radiation on their physiology and growth substrates, or indirect, through caloric and kinetic energy inputs and freshwater inputs, which determine the availability of essential elements, light and reducing power (Falkowski et al. 1998). In any case, predicting the health of Mediterranean marine ecosystems in response to global warming and other anthropogenic phenomena inevitably leads to understanding and predicting the adaptations of the planktonic community to the changing environment.

\subsubsection{Evidence of change}

Planktonic primary producers (phytoplankton). Most of the long-standing observations of phytoplankton biomass and species composition in the Mediterranean Sea are from coastal waters, and thus present human disturbances other than climate change that also affect marine ecosystems. Processes like eutrophication through coastal discharges, land mobilization and pollution have a potential to affect phytoplankton development at least as much as climate does, and separating them is a difficult task.

Between the 1970s and 1990s, a steady decrease in the water transparency, indicative of increased phytoplankton biomass, was observed in the Catalan 
Sea littoral (Duarte et al. 1999). This pattern, which was consistent with the observed trends in the Adriatic Sea (Solic et al. 1997, Mozeti et al. 2010, Ninčević Gladan et al. 2010), was not attributed to climate change but to the rise of nutrient inputs associated with the increase in the permanent and temporary human population on the coast. Throughout the last decade, however, the time series studies in the Gulf of Naples (Zingone et al. 2010), the Bay of Calvi, Corsica (Goffart et al. 2002), and the Adriatic Sea (Mozeti et al. 2010, Ninčević Gladan et al. 2010) have all shown what seems to be a common decrease in phytoplankton biomass. In semi-enclosed regions like the Adriatic Sea, this decrease has been attributed to reduced eutrophication by lowered nutrient discharges (Mozeti et al. 2010). Conversely, in the Bay of Calvi, which is less productive due to the influence of Atlantic waters and a lower input of external energy (wind) and continental waters, the decrease in the concentration of chlorophyll a ( $\mathrm{chl} a$ ) at the surface has been steady since the 1970s and has evolved concurrently with the increase in temperature between the 1970s and 1990s (Goffart et al. 2002).

The only time series held in open waters of the western Mediterranean is the DYFAMED station in the Ligurian Sea (Fig. 1). There, an increase in the phytoplankton biomass was observed during the 1990s, as inferred from increased concentrations of chl a integrated through the upper $250 \mathrm{~m}$ of the water column. This region is characterised by deep-mixing driven by strong winds, which causes light limitation in phytoplankton growth in winter, despite the presence of river-discharged nutrients. A lengthening of the stratification period implies a lengthening of the productive period, because it alleviates light limitation (Marty et al. 2002).

Therefore the sparse data available suggest that the potential effects of climate change on the biomass and productivity of phytoplankton largely depends on the littoral environmental pressure and the existing hydrodynamic regime (Table A1). In nearshore waters, local perturbations on geochemical fluxes have a much greater influence than does climate. In the open sea (off the shelf), 2 hydrodynamic regimes must be differentiated: (1) in the northernmost sector, the productivity of the seasonally strongly mixed waters may be increased due to climate warming as a result of the lengthened stratification period and the consequent alleviation of light limitation $_{i}(2)$ in most of the Catalan Sea, however, the lengthening of the already long-lasting stratification may prolong nutrient-depleted conditions and reduce annual productivity.
Besides the trends in the biomass and bulk activities, it is also important to consider whether there are changes in the phenology (cycles and timing) and structure of the phytoplankton communities. In Calvi Bay, the winter-spring bloom has moved forward from March to January-February, in line with the earlier stratification owing to the increase in temperature and sunny days and the decrease in wind speed (Goffart et al. 2002). In the Ligurian Sea, the above-mentioned increase in biomass is associated with important but variable changes in community structure. During the 1990s, a decrease in diatom abundance was observed together with an increase in the contribution of smaller organisms, nanoflagellates and picophytoplankton (Marty et al. 2002). The causes were most probably an uncompensated increase in new nutrient inputs derived from continental sources that are deficient in silicate (Béthoux et al. 2002). In the 2000s, however, strong convective mixing episodes associated with droughts led to episodic increases in diatom biomass (Marty \& Chiavérini 2010). Although both situations resulted in a general increase in productivity, the consequences of community structure shifts are important because the size of primary producers determines the magnitude of carbon export flows both to the sediments (important for the sea's role in absorbing atmospheric $\mathrm{CO}_{2}$ ) and the higher trophic levels (important for fisheries and for benthic invertebrates).

On the Catalan Sea coast, the only data that allow long-term comparisons are the data obtained in Blanes Bay, Spain, in the 1950s and 1960s by Margalef (1964) and the recent data collected by Scharek et al. (2007). The comparison shows that, for the largest phytoplankton (chain-forming diatoms and dinoflagellates), the dominant species have not changed; diatoms typical of more northern temperate waters are found in the bloom at the end of winter, and dinoflagellates typical of tropical waters are found at the end of spring and during summer. It is important to highlight, however, that this perception of no change in the large dominant species does not allow us to infer anything about whether there have been changes in the smallest phytoplankton or in the size distribution of the entire community.

Zooplankton. In the Balearic Islands, Fernández de Puelles \& Molinero (2008) observed a certain negative correlation between the positive interannual temperature anomalies and the abundance of zooplankton. The high NAO periods coincide with lower zooplankton abundances. In the Ligurian Sea, Molinero et al. (2005) observed phenological changes, possibly due to climatic causes, that affected the 
structure of the zooplankton community. They found that the higher NAO phases favour the copepod Centrophages and the lower phases favour Temora. Molinero et al. (2008b) also suggested that the dominance of the positive phases of the NAO since the 1980s has led to the progressive substitution of copepods by gelatinous zooplankton, because the latter are better filter feeders (more efficient with smaller phytoplankton) and are better adapted to the stability of the water column. This situation is also reinforced by the fact that gelatinous zooplankton also feed on copepods. Conversi et al. (2010) found an increase in zooplankton abundances after 1980, mainly due to the gelatinous component of the assemblages.

Bacterioplankton. An increase in the abundance of bacteria has been observed in the Adriatic Sea (Solic et al. 1997). At the Blanes Bay Microbial Observatory, the bacterial abundance in surface waters for the last 2 decades (1992 to 2009) does not show a clear trend through time (Duarte et al. 1999, www. icm.csic.es/bio/projects/icmicrobis/bbmo/). Also no conclusions can be made about the phenology and composition of the bacterial community because the molecular techniques used for determining the phylogenetic identity of the bacteria and their linkage with the activity in the ecosystem have only just developed over the last 7 to $8 \mathrm{yr}$.

Community metabolism. 'Community metabolism' can be defined as the balance between production and respiration of the entire plankton community as a whole, which results in a net balance of $\mathrm{CO}_{2}$ fixation and oxygen production, or $\mathrm{CO}_{2}$ production and oxygen consumption. Determining community metabolism requires taking continuous oxygen measurements, which can be compared with climatic data, or carrying out bottle incubation experiments to measure primary production and respiration rates, in which the environmental conditions can be manipulated to simulate changes associated with climate.

Experiments that confine and manipulate the plankton community, whether in bottles in the laboratory or in large containers installed in the sea, allow hypotheses to be tested, although extrapolating the results to the natural environment of the communities is problematic. This kind of experimental approach has shown, for example, that the higher trophic levels (small zooplankton) are the most vulnerable to gradual water warming over a few weeks (Petchey et al. 1999). Vázquez-Domínguez et al. (2007) carried out experiments with water from Blanes Bay sampled monthly over an entire year, and observed that with an increase in temperature of $2.5^{\circ} \mathrm{C}$, the carbon respiration of the heterotrophic microorgan- isms increased without increasing their growth efficiency; that is, in warmer waters the plankton consume more oxygen and produce more $\mathrm{CO}_{2}$. In fact, temperature is a determining factor of community metabolism because, at a physiological level, it accelerates respiration more than photosynthesis. Therefore, global warming directly favours plankton heterotrophy (net $\mathrm{CO}_{2}$ production). Climate change in the western Mediterranean Sea, with its hydrographical consequences, also seems to lead to a decrease in the export of organic carbon by sedimentation (Marty et al. 2002). Therefore, it also results in more recycling close to the surface by respiration, and thus indirectly accentuates the heterotrophy of the ecosystem. If we take into account that the solubility of $\mathrm{CO}_{2}$ also decreases with temperature, we see that everything points to a loss in the sea's capacity to absorb the growing quantities of atmospheric $\mathrm{CO}_{2}$.

\subsubsection{Predicted trends}

The tendency in the western Mediterranean Sea and the Catalan Sea, as in all the world's oceans, is for the length and intensity of stratification to increase with global warming. The climatic variability associated with the NAO can be used for predicting climate changes. The positive phases of the NAO, which involve higher atmospheric pressures and temperatures, and decreases in rainfall and wind force, favour the warming and stratification of the surface water in the open sea. Warming leads to a decrease in the solubility of $\mathrm{CO}_{2}$, and the strengthening of the stratification means that fewer nutrients arrive to surface waters (Fig. 7). Although the effect on the annual primary production is not completely clear, it does seem that these hydrographical changes will lead to (1) changes in the structure of the plankton communities and the metabolism of the ecosystem, which will favour the smallest plankton, (2) a relative increase in the respiration with respect to primary production (increase in heterotrophy) and (3) a decrease in the carbon exported to the seafloor and fish (Fig. 7). Overall, all these changes diminish the sea's capacity to absorb atmospheric $\mathrm{CO}_{2}$.

\subsection{Jellyfish on the coast}

Jellyfish are gelatinous planktonic heterotrophic organisms present in practically all marine environments of the world. When the conditions are favourable, they form dense swarms of individuals. 
In these cases, and understanding that they are very efficient at capturing prey, jellyfish channel a large part of the energy absorbed by the pelagic ecosystem in planktonic secondary production. Jellyfish are important from ecological and evolutionary perspectives, and in terms of their contribution to biodiversity. They are abundant as bycatch in the fishing industry, are a source of obstruction to power plant turbines, and can have a negative effect on tourism at beaches. Moreover, there is evidence that the problem will grow larger with global warming, pollution and overfishing (Purcell et al. 2007). Most of the energy that once circulated through fishes is now processed by other predators (especially Cnidaria and Ctenophora) that fill a gap within the trophic system (Mills 2001). Fishing activity continues to remove large predators and, as a result, carnivorous zooplankton proliferate. Jellyfish and other pelagic cnidarians are consumers of ichthyoplankton (i.e. fish larvae and eggs) in the world's oceans and seas, including the Catalan Sea (Lynam et al. 2005, Sabatés et al. 2010), and thus concentrate in waters where fish reproduce or lay their larvae and eggs (Purcell \& Grover 1990). Their presence in high numbers is thus detrimental for fisheries (Brodeur et al. 2002).

In the Catalan Sea coasts, the large jellyfish swarms observed at the beaches and the growing number of swimmers stung by these organisms have set off an alarm signal (Gili et al. 2010). This increase in jellyfish abundance has been discussed widely in the media, which has led to the launch of public health campaigns and environmental monitoring programmes. Unfortunately, systematically documented observations are scarce and relatively recent, which makes it difficult to study the relationship between the jellyfish swarms in local waters and climate change, as has been done in other areas (Purcell et al. 2007). However, the analysis of the existing data, together with the studies carried out in neighbouring regions and those climatically similar to the Catalan Sea, along with the growing knowledge of the life cycle of these organisms, allow us to outline the causes behind the abundance of jellyfish on the Catalan Sea coast and determine the most probable future trends.

\subsubsection{Evidence of change}

The Zoological Station of Villefranche-sur-Mer, France, has recorded the presence of the jellyfish, Pelagia noctiluca, on the coasts of the Ligurian Sea since the end of the 19th century. Combining these data with observations documented in other institu-
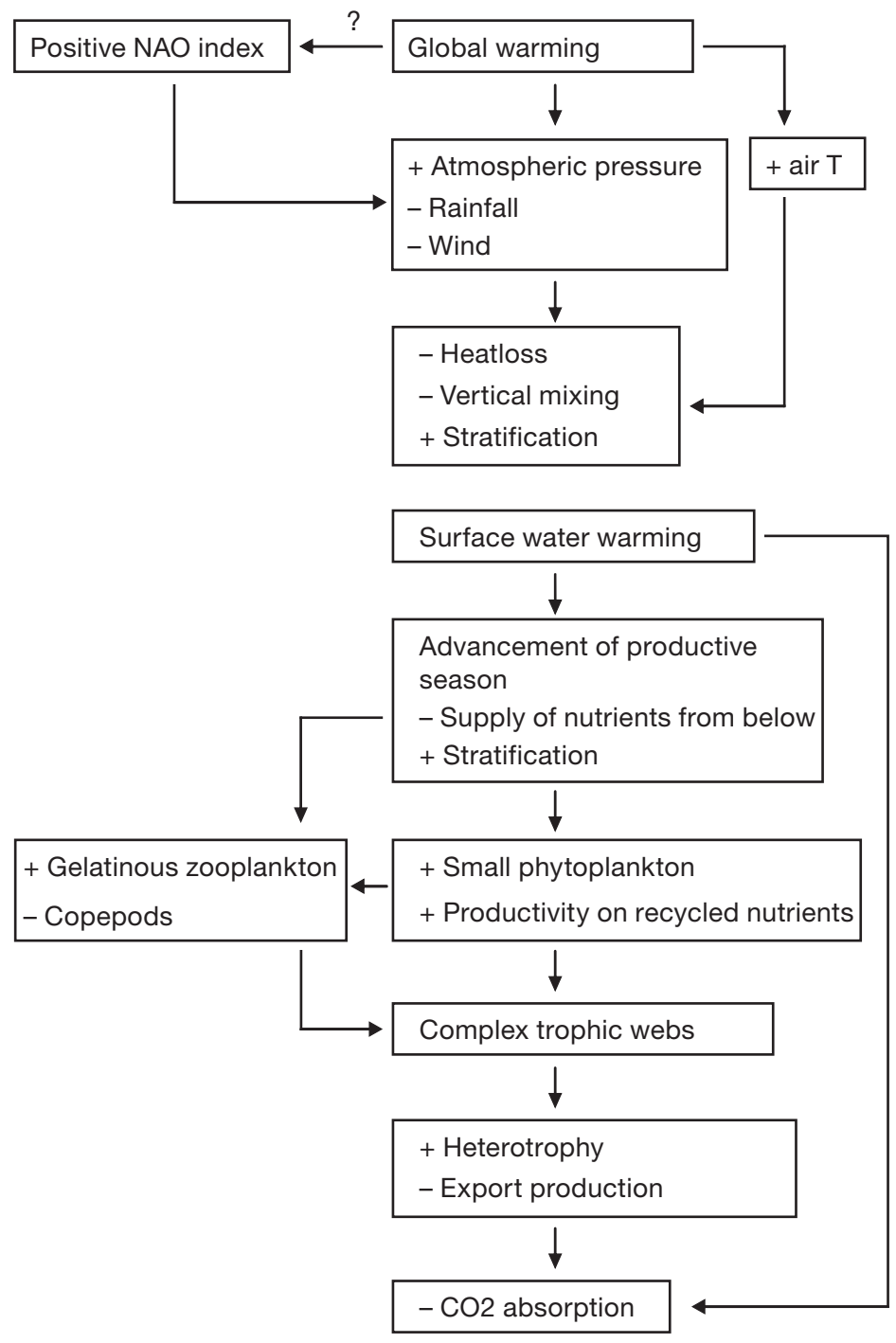

Fig. 7. Mechanisms by which climate change and global warming can affect pelagic ecosystems. The diagram summarises and illustrates graphically the explanation provided in Section 3.1. NAO: North Atlantic Oscillation

tions, it was possible to reconstruct a 200 yr time series (1785 to 1985) of the presence of this species (Goy et al. 1989). The finer analysis of the period from 1875 to 1985 showed a certain cyclic nature in the alternation of years with Pelagia and years without Pelagia. In fact, the contingency periodogram of this series indicated that approximately every $12 \mathrm{yr}$ there was a period of 2 to 5 consecutive years when jellyfish were present. The comparison with climate data showed that the years with jellyfish coincided with years with little rainfall, high temperatures and high atmospheric pressure from May to August, the reproduction period of Pelagia (Goy et al. 1989). In 
the last 2 decades, it seems that this alternating tendency with a marked periodicity has been modified and jellyfish intrusions are more frequent. Jellyfish appearance along the Catalan Sea coast shows maxima in abundance every 3 to $4 \mathrm{yr}$ instead of the previously observed 12 yr period (Gili et al. 2010; Fig. 8A). Furthermore, similar observations have been made in areas all over the planet, which suggests that it is a worldwide phenomenon (Purcell et al. 2007). Over the last $5 \mathrm{yr}$, there has also been a change in the dominant species that proliferate on the coast, with increasing abundance of littoral species like Rhizostoma pulmo and the displacement of offshore species like $P$. noctiluca (Fuentes et al. 2011; Fig. 8B). This is because littoral species normally present both an asexual phase (polyp) and a pelagic sexual phase (medusa) while offshore species only present a medusa stage in their life cycle. The polyp phase is believed to benefit from increasing temperatures, which would enhance polyp survival to the medusa stage.

Since 2000, and especially in the last $5 \mathrm{yr}$, an increase in jellyfish swarms has been observed close to the Catalan Sea coast along with an increase in the duration of the blooms. Moreover, there now appear to be more species that form large swarms. The proliferation of jellyfish on the coasts and beaches depends mainly on 2 factors: (1) the conditions for growth and reproduction in areas far from the coast, where the most abundant species reaching the beaches originate; (2) the transport of the swarms from the open sea and their accumulation close to the coast (Sabatés et al. 2010).

Carnivorous gelatinous organisms are particularly responsive to temperature and climatic oscillations (Molinero et al. 2008a). The increase in temperature positively affects both their growth and reproductive success, which has already been proposed as a direct cause of the increase in jellyfish swarms in other seas (Arai 1997, Brodeur et al. 1999). It also seems to be the reason behind the proliferation in temperate waters of thermophilic species normally associated with subtropical waters. An example of the latter phenomenon is the observation in 2009 for the first time on the Catalan coasts of the ctenophore, Mnemiopsis leidyi (Fuentes et al. 2009). The success of introduced $M$. leidyi has been attributed mainly to the reduced competition due to overfished populations of zooplanktivorous fish and the lack of predators (Siapatis et al. 2008). The proliferation of other important invasive species such the cubemedusa Carybdea marsupialis in the western Mediterranean Sea have been related to the increase of water tem-
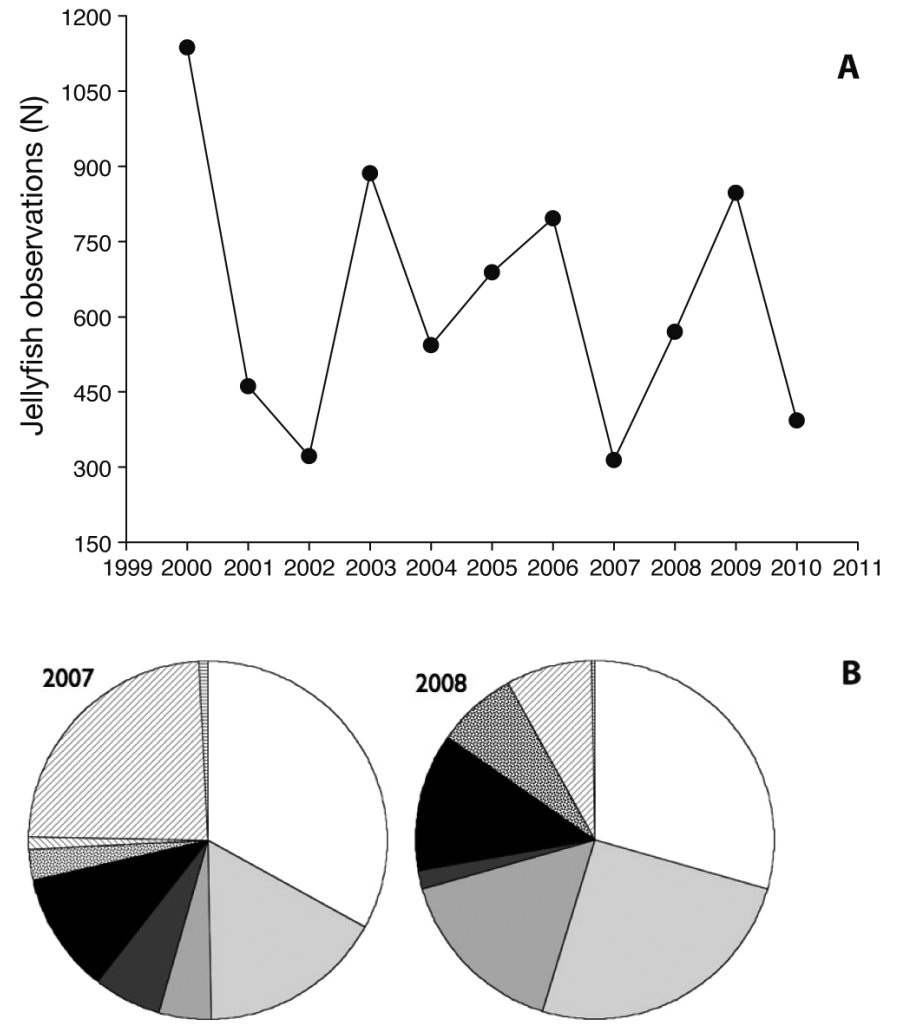

B
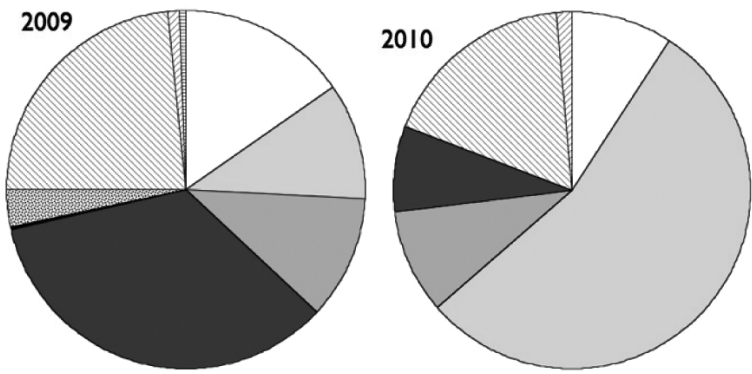

$\square$ Pelagia noctiluca $\square$ Rhizostoma pulmo

$\square$ Cotylorhiza tuberculata

Velella velella

Aurelia aurita

目 Others 國 Chrysaora hysoscellio

$\$$ Aequorea forskalea

Species not determined

Fig. 8. (A) Total number of jellyfish observations on the Catalan coast from 1999 to 2011. 'Observation' indicates the presence of jellyfish blooms with more than 3 individuals $\mathrm{m}^{-2}$. The frequency and location of sightings were constant over the period of study, with a total of 15000 sightings during the summer months. (B) Distribution of the different species of jellies detected on the Catalan coast between 2007 and 2010

perature and to the increased chances for polyp settlement in artificial substrata such as new small tourist harbours (Bordehore et al. 2011).

However, as mentioned previously, the physiological effects of temperature by itself do not explain the increase in the jellyfish swarms on the beaches and coasts during summer months. While it is true that, owing to the reproductive cycle, the blooms of most 
jellyfish reach maximum abundance between the beginning of spring and the end of summer, these abundance peaks are located about 30 to $60 \mathrm{~km} \mathrm{(20}$ to 40 miles) from the coast on the limit of the continental shelf. In these areas, hydrographic conditions favour relatively higher plankton production than in the neighbouring, more-stratified, nutrient-poor waters. In fact, in deep waters of the Ligurian Sea an increase in gelatinous plankton has been observed since the 1980s, without the copepods and chaetognaths having increased proportionally (Molinero et al. 2008b, Conversi et al. 2010). For jellyfish swarms to reach the beaches there needs to be transport from the open sea. During the day, jellyfish are situated in deep layers of the water column where they find more food and avoid visual predators; at night they rise up to the surface. The evening sea breezes push the jellyfish towards the coast and beaches, mainly in the summer. Therefore, the period of maximum abundance coincides with the period of maximum intensity of the breezes (Zavodnik 1987).

There is another climatic phenomenon that favours coastal swarms of jellyfish. In the spring and summer, freshwater inputs from rivers and aquifers lower the salinity and temperature, and therefore the density, of the coastal water. The water density becomes discontinuous, which makes it difficult for surface water, and therefore jellyfish, from the open sea to reach the coast (J. M. Gili unpubl. data). The gradual warming of the Mediterranean climate involves a warming of the shallow coastal waters in spring and summer, and the decrease in the rainfall means that the freshwater inputs are increasingly scarce. This leads to the early homogenisation of the coastal waters with water from the open sea, which facilitates the wind action and the arrival of jellyfish to the coast.

\subsubsection{Predicted trends}

There is little quantitative data for past or present jellyfish populations. However, as the quality of the data improves, and jelly species are correctly identified, we will see a more accurate view of the response of gelatinous plankton populations to climate change. However, some studies and observations already point to likely future trends. A study by Molinero et al. (2008a) shows that positive phases of the NAO favour jellyfish blooms in the northwestern Mediterranean Sea. These periods have higher temperatures and atmospheric pressures, as well as a lower rainfall (and therefore less river discharge) and wind force (Lloret et al. 2001). Together these factors promote surface warming and stratification in the open sea, the development of gelatinous carnivores and their transport towards the coast (Fig. 7). This climatic trend, along with the fact that other anthropogenic pressures (see Section 4) are also unlikely to decrease, points to a progressive increase in the presence of jellyfish swarms on the Catalan Sea coast over the upcoming years.

\subsection{The Mediterranean coralligenous community}

The coralligenous community is a structure of biogenic origin produced by the accumulation of encrusting algae in low light conditions. The animal communities in the coralligenous assemblages vary according to light, currents, sedimentation processes and temperature. In the more eutrophic areas such as the northwestern Mediterranean Sea, gorgonian corals dominate the community together with a wide range of other suspension feeders such as sponges, bryozoans and ascidians. The coralligenous community is symbolic of the Mediterranean, and is highly appreciated by the diving tourism industry. It is biologically important because of its high species diversity (up to 1666 species, Ballesteros 2006) and the great structural complexity created by some of the main building species (encrusting algae, gorgonians and sponges). This complexity contributes decisively to maintaining the biological diversity. However, it is a very vulnerable community, due to the longevity and low turnover of most of the species that constitute it, especially the building species (Coma et al. 1998, Garrabou et al. 2002). These characteristics lead to slow growth and low recruitment, greatly reducing the capacity of the community to recuperate when it undergoes disturbances.

\subsubsection{Evidence of change}

In recent years, global warming has severely affected marine benthic ecosystems through epidemic diseases and mass mortalities of the organisms (Harvell et al. 1999). The alarm signal sounded in the coral reef ecosystems during the severe coral bleaching events in 1997 and 1998 (Harvell et al. 2002). Recently, both the physical and biological evidence that has accumulated shows that the Mediterranean Sea is suffering the effects of global warming (Table A1). During the summer of 1999, there was a mass mortality event of invertebrates that affected 
more than $500 \mathrm{~km}$ of the northwestern Mediterranean coastline between Italy and France as well as the north coast of Menorca (Perez et al. 2000, Coma et al. 2006). Another mass mortality event with the same characteristics as that of 1999, but with a larger geographic extension, occurred at the end of the summer of 2003, again in the northwestern Mediterranean. In this case the affected area was several thousand kilometres of coastline from the Gulf of Naples to the Catalan Sea, including Corsica and Sardinia, the Gulf of Genoa, the Provençal coast and the Balearic Islands (Garrabou et al. 2009). In both events the populations of sessile invertebrate suspension feeders of the coralligenous community between 0 and 35 to $45 \mathrm{~m}$ depth were the most affected, especially the gorgonian and sponge populations (Table 2). The colonial nature of most of these species means that they can suffer partial mortality, while the colony still survives. This capacity has attenuated the effect of mass mortality events on populations. Nevertheless, in many areas the losses have been approximately $50 \%$ of the gorgonian populations (Linares et al. 2005, Coma et al. 2006) and up to $95 \%$ for some sponge populations (Maldonado et al. 2010, Cebrian et al. 2011). Evidence of increased recruitment after an event has been observed in some populations indicating that clear-cut restoration trends may occur (a self-thinning process, the reduced population favouring the survival of recruits by decreasing intraspecific competition; Linares et al. 2008a, Cupido et al. 2009) if mass mortality events do not occur frequently. However, if these events do become frequent, the effect in decreasing gonadal output of colonies (Linares et al. 2008b), limiting dispersal (Ledoux et al. 2010, Blanquer \& Uriz 2010, Mokhtar-Jamaï et al. 2011) and fragmenting of populations may drive the population to a threshold where persistent population decline occurs (Linares 2010).

The causes of the mass mortalities of invertebrates are related to climate change and its effects. Some hypotheses on the triggering mechanisms have been proposed (Cerrano et al. 2000, Romano et al. 2000, Coma \& Ribes 2003, Bally \& Garrabou 2007, Torrents et al. 2008, Coma et al. 2009, Bensoussan et al. 2010, Lejeusne et al. 2010, Vezzulli et al. 2010) and include: (1) organisms being exposed to temperatures above the thermal tolerance level of the species, (2) organisms being exposed to temperatures under their critical temperatures, but which still cause physiological stress, and (3) increase in the virulence of pathogenic microorganisms. The mass mortality events have not been characterised by physiologically critical temperatures, although we cannot completely dismiss this possibility, as critically high temperatures could have occurred locally. Concerning the hypothesis of virulent microorganisms, even though microorganisms have been found (Bally \& Garrabou 2007), they have been identified as opportunistic (Cerrano et al. 2000, Martin et al. 2002, Vezzulli et al. 2010). The temperatures at the end of summer during these events were 3 to $4^{\circ} \mathrm{C}$ above the average and there was a stable water column that would have delayed the vertical mixing that usually occurs at the end of summer and beginning of autumn. These conditions are not critical for the organisms, but can cause physiological stress.

Recently, laboratory experiments and field observations have demonstrated that climate anomalies of extreme stratification are one of the main causes of mortality events of certain invertebrate suspension feeder species of the coralligenous community (Coma et al. 2009). The mechanism that triggers death is physiological stress due to energetic limitations. Summer is energetically unfavourable for these organisms, due to the high temperatures demanding increased respiration, and low food availability, which does not allow them to feed sufficiently to meet this high respiratory demand, causing the organisms to irreversibly lose biomass. The organisms are able to support a 'normal' duration of energetically adverse conditions during summer, but not an abnormal extension of these conditions, particularly if this extension occurs in combination with unusually high temperatures. Mass mortality events occurred in years of prolonged conditions of the period of strong stratification of the water column (Coma et al. 2009). Short periods of unusually high temperatures have been suggested recently as the possible triggering factor of sponge diseases (Ircinia spp., Maldonado et al. 2010, Cebrian et al. 2011). However, little is known about how these pathogens will be affected by the present environmental changes. The effects of high temperatures on these organisms are being studied using stress resistance indicators, such as thermal shock proteins and the production of chemical defences (Lejeusne et al. 2010).

\subsubsection{Predicted trends}

Mass mortality events have occurred before in the northwest Mediterranean Sea. In September 1983, a mass mortality event affected the red coral populations up to $20 \mathrm{~m}$ depth in the Ligurian Sea (Harmelin 1984). Since then, other mortality events, mainly affecting cnidarians and sponges, have been ob- 
Table 2. List of documented mass mortality events of invertebrates in the northwestern Mediterranean Sea. Extension: order of magnitude of affected coastline

\begin{tabular}{|c|c|c|c|c|c|c|c|}
\hline Year & Location & $\begin{array}{l}\text { Extension } \\
\quad(\mathrm{km})\end{array}$ & n Scale & $\begin{array}{l}\text { Depth } \\
\text { range }(\mathrm{m})\end{array}$ & Taxon & Species & Reference \\
\hline 1983 & La Ciotat (Ligurian Sea) & $10^{0}$ & Local & 0 to 20 & Cnidaria & $\begin{array}{l}\text { Corallium rubrum } \\
\text { Eunicella singularis }\end{array}$ & Harmelin (1984) \\
\hline \multirow[t]{2}{*}{1987} & $\begin{array}{l}\text { Massala Lagoon } \\
\text { (northwestern Sicily) }\end{array}$ & \multirow[t]{2}{*}{$10^{0}-10^{1}$} & \multirow[t]{2}{*}{ Local } & \multirow[t]{2}{*}{0 to 18} & \multirow[t]{2}{*}{ Porifera } & $\begin{array}{l}\text { Spongia officinalis } \\
\text { Anchinoe paupertas }\end{array}$ & Gaino \& Pronzato (1989) \\
\hline & $\begin{array}{l}\text { Portofino (eastern } \\
\text { Ligurian Sea) }\end{array}$ & & & & & Ircinia variabilis & Gaino et al. (1992) \\
\hline 1992 & $\begin{array}{l}\text { Medes Islands (north- } \\
\text { western Mediterranean) }\end{array}$ & $10^{0}$ & Local & 0 to 13.5 & Cnidaria & Paramuricea clavata & Coma \& Zabala (1992) \\
\hline 1993 & Sicily (southern Italy) & $10^{0}$ & Local & 0 to 39 & Cnidaria & Paramuricea clavata & Mistri \& Ceccherelli (1996) \\
\hline 1994 & $\begin{array}{l}\text { Portofino Promontorio } \\
\text { (Ligurian Sea) }\end{array}$ & $10^{0}$ & Local & 0 to 35 & Cnidaria & Paramuricea clavata & Bavestrello et al. (1994) \\
\hline 1994-1996 & $\begin{array}{l}\text { Porto Cesareo } \\
\text { (South Adriatic Sea) }\end{array}$ & $10^{0}$ & Local & 0 to 1 & Porifera & $\begin{array}{l}\text { Ircinia spinosula } \\
\text { Ircinia sp. }\end{array}$ & Corriero et al. (1996) \\
\hline \multirow[t]{2}{*}{$1997-1999$} & Gulf of La Spezia & \multirow[t]{2}{*}{$10^{1}$} & \multirow[t]{2}{*}{ Local } & & \multirow{2}{*}{ Cnidaria } & Cladocora caespitosa & Rodolfo Metalpa et al. (2000) \\
\hline & (Ligurian Sea) & & & & & Balanophylia europaea & Rodolfo-Metalpa et al. (2005) \\
\hline 1999 & $\begin{array}{l}\text { Coast of Provence } \\
\text { and Ligurian Sea }\end{array}$ & $10^{2}$ & Regional & 0 to 45 & Cnidaria & 7 species & Cerrano et al. (2000) \\
\hline \multirow[t]{4}{*}{1999} & \multirow{4}{*}{$\begin{array}{l}\text { Coast of Provence } \\
\text { and Ligurian Sea }\end{array}$} & \multirow[t]{4}{*}{$10^{2}$} & \multirow[t]{4}{*}{ Regional } & \multirow[t]{4}{*}{0 to 45} & Porifera & 12 species & \multirow[t]{4}{*}{ Perez et al. (2000) } \\
\hline & & & & & Bryozoa & 4 species & \\
\hline & & & & & Bivalvia & 2 species & \\
\hline & & & & & Ascidiacea & 3 species & \\
\hline 1999 & \multicolumn{3}{|l|}{$\begin{array}{l}\text { Provence region (north- } \\
\text { western Mediterranean) }\end{array}$} & 13 to 26 & Cnidaria & Corallium rubrum & Garrabou et al. (2001) \\
\hline 1999 & \multicolumn{2}{|l|}{$\begin{array}{l}\text { Balearic Islands (north- } \\
\text { western Mediterranean) }\end{array}$} & & 0 to 40 & Cnidaria & Eunicella singularis & Coma et al. (2006) \\
\hline 2002 & $\begin{array}{l}\text { Ischia and Procida } \\
\text { Islands (Tyrrhenean Sea) }\end{array}$ & a) $10^{1}$ & Local & & Cnidaria & $\begin{array}{l}\text { Paramuricea clavata } \\
\text { Eunicella singularis }\end{array}$ & Gambi et al. (2006) \\
\hline 2003 & $\begin{array}{l}\text { Gulf of Genova, } \\
\text { Provence coast, Corsica- } \\
\text { Sardinia, Gulf of Naples, } \\
\text { Balearic Islands, Catalan } \\
\text { coast }\end{array}$ & $\begin{array}{ll} & 10^{3} \\
\text { si } & \\
\text { in } & \end{array}$ & Regional & 0 to 40 & $\begin{array}{l}\text { Cnidaria } \\
\text { Porifera } \\
\text { Bryozoa } \\
\text { Bivalvia }\end{array}$ & $\begin{array}{l}9 \text { species } \\
9 \text { species } \\
2 \text { species } \\
5 \text { species }\end{array}$ & Garrabou et al. (2009) \\
\hline 2005 & Columbretes Islands & $10^{0}$ & Local & 0 to 16 & Mollusca & $\begin{array}{c}\text { Spondylus gaeropus } \\
\text { Barbatia barbata } \\
\text { Arca noe }\end{array}$ & Kersting et al. (2006) \\
\hline 2005 & $\begin{array}{l}\text { Phlaegrean Island } \\
\text { (Tyrrhenean Sea) }\end{array}$ & $10^{1}$ & Local & & Cnidaria & $\begin{array}{l}\text { Eunicella cavolinii } \\
\text { Eunicella singularis } \\
\text { Paramuricea clavata }\end{array}$ & Cigliano \& Gambi (2007) \\
\hline 2007 & $\begin{array}{l}\text { Cabo de Palos-Cabrera } \\
\text { Island (northwestern } \\
\text { Mediterranean) }\end{array}$ & $10^{0}-10^{1}$ & Local & 0 to 45 & Cnidaria & $\begin{array}{l}\text { Eunicella singularis } \\
\text { Paramuricea clavata }\end{array}$ & Coma et al. (2007) \\
\hline 2008-2009 & $\begin{array}{l}\text { Cabrera Island, } \\
\text { Scandola National Park, } \\
\text { Chafarinas Islands } \\
\text { (northwestern } \\
\text { Mediterranean) }\end{array}$ & $10^{2}$ & Regional & 0 to 15 & Porifera & $\begin{array}{c}\text { Ircinia fasciculata } \\
\text { Sarcotragus spinosulum }\end{array}$ & $\begin{array}{l}\text { Maldonado et al. (2010) } \\
\text { Cebrian et al. (2011) }\end{array}$ \\
\hline
\end{tabular}

served in the western basin (Table 2). A common characteristic of the events that occurred until 1999 was their localized distribution, in which damage affected tens of metres or kilometres. The 1999 episode was the first large regional event recorded (affecting hundreds of kilometres). The two extreme regional scale events (1999 and 2003) occurred concurrently with extreme events of stratification (Coma et al. 2009). The current warming pattern and the observation that there is a relationship between the maximum temperature in summer and the lengthening of the stratification period (Coma et al. 2009) suggest that there will be an increased probability of long, hot summers in the northwest Mediterranean Sea and, therefore, in mass mortality events similar to those described above. This is consistent with the 
pattern of increasing length of coastline affected by mass mortality events (Fig. 9). At present, the exposure to temperatures causing physiological stress under summer low-food conditions appears to be the main cause of major mass mortality events. However, the present warming trend forecast indicates a near future scenario that could increase current late summer metabolic stress, causing an increased production of heat shock proteins and a decrease in the production of chemical defences (Agell et al. 2001, Thomas et al. 2007). These circumstances would make organisms more susceptible to opportunistic, residential and pathogenic microorganisms, with an expected increase in virulence (Coma et al. 2009, Lejeusne et al. 2010, Vezzulli et al. 2010). Under this scenario, the exposure of organisms to lethal temperatures and susceptibility to opportunistic and pathogenic microorganisms may become more frequent. Regional hydrographic conditions are contributing to the explanation of the variability in the impact of mass mortality events in the Mediterranean Sea and to helping understand why the Catalan coast has, so far, been less affected than other northwestern Mediterranean areas (Garrabou et al. 2009, Bensoussan et al. 2010). The causal relationship between global warming and mass mortality events, reinforced by the observed increasing trend in the frequency and intensity of these events (Table 2, Fig. 9), suggests that there will be huge changes in the composition of the Mediterranean coralligenous community situated above the summer level of the thermocline. Increased frequency of mass mortality events suggests that the community may show a tendency to shift its upper distribution limit to a deeper level.

The effects of extreme events of warming and stratification on the coralligenous community are

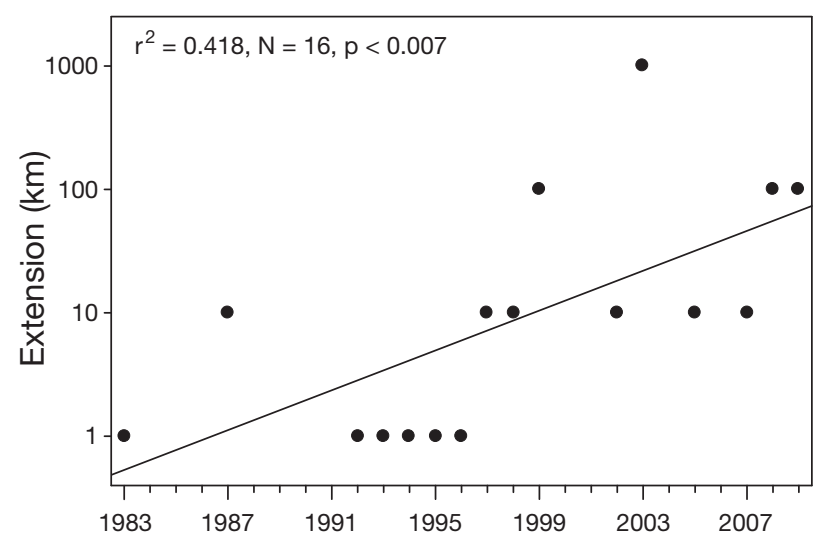

Fig. 9. Extension of the northwestern Mediterranean coastline affected by the documented mass mortality events. Note the $y$-axis is in log scale among the clearest observations of biological effects associated with climate change (Coma et al. 2009). In this sense, the coralligenous community is one of the best indicators of climate change in the Catalan Sea and, in general, the northwestern region of the Mediterranean Sea (Ros 2009). Thus, given the evidence of limited dispersal of the main building species (Blanquer \& Uriz 2010, Ledoux et al. 2010, Mokhtar-Jamaï et al. 2011), there is also an urgent need to act locally or regionally against the other relevant human disturbances, such as trawl fishing and waste water pollution (see Section 4), that reinforce climate change effects, if we are to avoid local extinction processes.

\subsection{Fish populations}

The ichthyofauna channels a significant part of the energy fixed by primary production, structures the biological community (playing a role at several trophic levels) and contributes to biodiversity (Worm et al. 2006). Climate change has both direct and indirect effects on fish populations. Direct effects act on their physiology and behaviour and indirect effects alter the productivity, structure and composition of the marine ecosystems on which fish depend for food (Brander 2010). Temperature is the most important abiotic variable governing growth, reproduction and survival of fishes (Magnuson et al. 1979, Stephens et al. 1988) and it determines species distribution, since different species have different fundamental thermal niches (Magnuson et al. 1979). The western Mediterranean region is characterised by a well defined seasonality, with relatively cold winters in the north and long hot periods in the south that are almost like those of subtropical regions. This latitudinal gradient marks the distribution of the species and their exploitation: the more thermophilic species are found along the coasts of North Africa and the southeastern Iberian Peninsula, while to the north, on the Catalan Sea coast and the Ligurian Sea, the species present are typical of colder waters. The most recent climate change is changing the 'traditional' geographic distribution patterns of fishes.

However, it is difficult to distinguish changes associated with climate variability from those related to other anthropogenic factors. Climate change is an additional pressure on top of many already experienced by fish stocks, such as fishing, loss of habitat, pollution and disturbance from introduced species (Brander 2010). This mix of pressures and forcings over fish populations, common to the entire planet 
(Pauly et al. 1998), is also affecting the Mediterranean and the Catalan seas.

In addition, these climate- and human-induced changes in fish populations will have an effect on top predators like seabirds or cetaceans, whose distribution, abundance and migration largely depend on prey availability. An example of both direct and indirect effects of climate change on seabirds is the northward expansion of the endangered Balearic shearwater Puffinus mauretanicus. Their expansion into northeast Atlantic waters was attributed to a direct effect of warmer temperatures and an indirect effect through the influence of temperature on the distribution and composition of zooplankton, which nourish their fish prey (Wynn et al. 2007, Luczak et al. 2011). Recently, Gambaiani et al. (2009) highlighted the potential effects of climate change, in particular sea warming and the reduction of prey resources, on Mediterranean cetaceans such as common dolphins Delphinus delphis, bottlenose dolphins Tursiops truncatus or striped dolphins Stenella coeruleoalba.

\subsubsection{Evidence of change}

There is evidence that Mediterranean biodiversity patterns are changing and that these changes could be related to the increasing seawater temperature. Fish and benthic species from the warm waters of the southernmost parts of the Mediterranean are extending their distribution range to the north (e.g. Francour et al. 1994, Astraldi et al. 1995, Riera et al. 1995, Bianchi \& Morri 2000, CIESM 2008a). More than 30 Mediterranean warmwater indigenous fish species have now been recorded north of their original geographical distribution. Similar poleward extensions have also been recorded outside the Mediterranean Sea (CIESM 2008a). Conversely, since the 1980s the abundance of some boreal species has dramatically decreased (Quignard \& Raibault 1993, CIESM 2008a).

As an example, the ornate wrasse Thalassoma pavo, a warmwater species that lives in rocky habitats, is now commonly found on the Catalan Sea coast and the Gulf of Lion, while a few decades ago it was only found abundantly in more southern areas. The same is also the case for the pearly razorfish Xyrichtys novacula, the bluefish Pomatomus saltatrix, the bastard grunt Pomadasys incisus and the dusky grouper Epinephelus marginatus (Francour et al. 1994). In the case of this last representative species, sea warming seems to favour their reproduction in the Catalan Sea (Zabala et al. 1997). Nevertheless, other factors such as the increase in density of populations, due to establishment of marine protected areas in the last $20 \mathrm{yr}$, and recent modification of the sex ratio of populations, could have improved their reproductive success (Bodilis et al. 2003). The warming of the Mediterranean waters could also modify species' migration. Bluefin tuna Thunnus thynnus and the amberjack Seriola dumerili, for example, have lengthened their stay in northern and central Mediterranean waters before migrating towards their winter territories (Bombace 2001).

Recently, an increasing abundance and northward expansion of the round sardinella Sardinella aurita have been reported in the Catalan Sea (Sabatés et al. 2006). This species is a thermophilic, small, pelagic fish particularly abundant in the warm waters of the eastern as well as in the southwestern Mediterranean basin. A positive relationship was established between round sardinella catches and temperature anomalies in the western Mediterranean. A gradual increase in species abundance was also observed from south to north, with a certain time lag going northwards, associated with the increase in seawater temperature. Furthermore, successful reproduction of this species on the northern Catalan coast was reported close to the edge of its distribution range, confirming its establishment in the new distribution areas (Sabatés et al. 2009). Concurrently, sprat Sprattus sprattus, a coldwater species and very common on the Catalan Sea coast in the 1950s (Vives \& Suau 1956) has practically disappeared from commercial landings in the last $25 \mathrm{yr}$ (Catalan Government unpubl. fishing statistics).

Long-term fluctuations in abundance of small pelagic fishes in relation to climate variability and ocean regime shifts have been described in different regions around the world (e.g. Lluch-Belda et al. 1989, Kawasaki 1992). Small pelagic fishes have a short life span and feed on a short, plankton-based food chain, and their recruitment is controlled to a large extent by egg and larval survival that, in turn, is dependent on the prevalence of suitable oceanographic and climatic conditions. In the Catalan Sea coast, the sardine Sardina pilchardus and anchovy Engraulis encrasicolus are the most abundant small pelagic fishes. Fluctuations in abundance of these 2 species has been linked to local environmental conditions such as runoff from the Ebre and Rhône rivers, wind mixing, sea surface temperature and surface chl a during the previous spawning period (Lloret et al. 2001, 2004, Palomera et al. 2007, Martín et al. 2008). This may be explained by the increase of planktonic productivity as a result of river inputs, and 
vertical mixing due to wind and low temperature, favouring spawning, feeding and survival of larvae. Recently, Martín et al. (2011) indicated that the WeMO regional index could provide an accurate representation of the environmental conditions affecting small pelagic fish production in the Catalan Sea. In this area, the abundance of these 2 species has fluctuated in synchrony over the last $30 \mathrm{yr}$. Positive WeMO phases, that is, low sea surface temperature, increased river flow and strong wind mixing, are favourable for the overall biological productivity in the Catalan Sea. In turn, this set of environmental factors would enhance survival and growth of sardines and anchovies during their life cycle, thereby increasing their recruitment (Martín et al. 2011).

The effect of climatic conditions on the dynamics of exploited populations has also been reported on demersal resources. Lloret et al. (2001) showed that Rhône River run-off was negatively affected by high NAO episodes. Although no relationship was established between NAO and fishery productivity of the northern Catalan coast, catches of different species were positively correlated with Rhône River outflow and the wind-mixing index during the previous spawning season. Thus, periods of low NAO index, generally coincident with high river run-off, tend to be more productive, favouring the recruitment and productivity of exploited stocks (Lloret et al. 2001). Similarly, in the Gulf of Lion, catches of the common sole Solea solea were also correlated with floods of the Rhône River (Salen-Picard et al. 2002) and with the abundance of polychaetes, their main prey. The increase in food after flooding events might favor the different stages of the sole's life cycle, enhancing its population size. In the Balearic Islands, Massutí et al. (2008) demonstrated that regional and global climate indices, such as NAO and MO, would influence the population dynamics of hake Merluccius merluccius and the deep-sea red shrimp Aristeus antennatus, favouring productivity and benefiting the recruitment of these species. On the Catalan coast, long-term variability in catches of the red shrimp and in the composition and diversity of deep sea communities have also been related to climatic oscillations (Maynou 2008, Cartes et al. 2009). Low or negative NAO phases, enhancing precipitation and river runoff, increased food input to deep benthos, which favour stocks of bottom-feeding species such as the red shrimp (Cartes et al. 2009). An enhancement of the recruitment process of this species and an increase of its total landings during the following years have also been associated with the formation of dense and cold shelf waters and their subsequent downslope cascade inside submarine canyons, which is a climate-induced phenomenon (Company et al. 2008).

Feeding and survival of fish larvae and planktivorous fish may be affected by changes in the abundance and composition of food. Although no series of planktonic data are available for the Catalan Sea, Molinero et al. (2005, 2008b) and Fernández de Puelles \& Molinero (2008) provided evidence of changes in the composition and phenology of the zooplankton (especially onset dates) associated with climate change for the Ligurian Sea and the Balearic Islands. According to those studies, the zooplankton is less abundant during high NAO phases (see Section 3.1.1). This would affect feeding and survival of fish larvae and subsequent recruitment. A paradigmatic case in this sense is Atlantic cod Gadus morhua in the North Sea. Declines in cod recruitment have been related to changes in the plankton ecosystem, due to rising temperatures since the mid-1980s, in a way that reduced the survival of larval cod (Beaugrand et al. 2003).

The relationship between recruitment of Mediterranean species and local (temperature, river discharges, wind conditions) and global (NAO, WeMO, $\mathrm{MO}$ ) environmental conditions indicates the trophodynamic relationship between climate variability and fishery yields and illustrates how climatic forcing could influence the dynamics of ecosystem functioning at short- and long-term scales.

\subsubsection{Predicted trends}

The gradual warming predicted for the Mediterranean Sea, the intense fishing activity and the loss and degradation of habitat involve changes in the specific composition and abundance of fish communities. The progressive establishment on the northern Catalan Sea of species from more southern latitudes also seems to be irreversible; what needs to be studied is how these fish assemblage modifications might affect ecosystem function. It is uncertain what will happen to coldwater species living in the northern and colder areas of the western Mediterranean basin. Because they cannot move farther north, they may dramatically decrease in number or even be at risk of extinction (CIESM 2008a, Ben Rais Lasram et al. 2010). Moreover, evidence shows that Lessepsian fish species from the Red Sea have succeeded in invading the western basin of the Mediterranean Sea (e.g. Azzurro \& Andaloro 2004, Dulçic \& Pallaoro 
2004, Daniel et al. 2009) because of global warming (Raitsos et al. 2010). Consequently, the spatial overlap between endemic and exotic fish species may lead to a reduction in the abundance and, in the future, a gradual replacement of endemic by exotic species (Ben Rais Lasram \& Mouillot 2009). As those authors pointed out, this is a key issue in the conservation of biodiversity. In addition, temperature may also affect sex ratios in fishes, a key demographic variable crucial for population viability (OspinaÁlvarez \& Piferrer 2008). Although it is still unclear to what extent a temperature increase may determine sex ratios in Mediterranean fishes, this effect will probably be more evident in the populations located on the geographic distribution limit of the species (Sabatés et al. 2006).

As indicated above, the predicted increase in water temperatures, lower wind stress and precipitation and the consequently higher stratification have also driven changes in the composition and phenology of planktonic communities (Molinero et al. 2005, 2008b) and the population size of gelatinous carnivores (Molinero et al. 2008a). These shifts may involve changes in trophic interactions of pelagic communities (Rossi et al. 2006) affecting the survival and growth of larvae and planktivorous fishes through effects on their prey, competitors and predators (Stige et al. 2010). Jellyfish outbreaks, for example, may significantly increase predation on fish larvae and competition with planktivorous fishes (Purcell \& Arai 2001, Sabatés et al. 2010).

The exploited state of Mediterranean fishes can impair their resilience to climate change perturbations. Recent studies have shown how fishing can change the demographic structure of commercially targeted species and, therefore, the ability of populations to cope with a changing environment (Hidalgo et al. 2011). In the Mediterranean Sea, a large proportion of catches consists of young individuals (Lleonart \& Maynou 2003) and exploitation is highly dependent on recruitment, making such populations more sensitive to climate variability. Thus, it is evident that effects of climate change cannot be estimated without incorporating other human stressors. Marine ecosystems constitute 'social-ecological systems', including natural and human components, which are highly interconnected and interactive (Perry et al. 2010). In this context, it is important to develop integrated observational and modelling systems to quickly recognise changes, including those occurring due to human activity, to provide meaningful and realistic projections of climate change effects on natural resources (Barange et al. 2010).

\section{ADDITIONAL ANTHROPOGENIC FACTORS AND POTENTIAL SYNERGIES}

Climate change is only one of the anthropogenic stressors that are negatively affecting marine organisms and ecosystems. Additional human-related pressures include habitat destruction, overfishing, pollution and introduction of exotic species, to name a few. In addition to global warming, the increase in atmospheric $\mathrm{CO}_{2}$ and its subsequent effect on ocean chemistry, have potentially negative consequences for many calcifying marine organisms (Fabry et al. 2008), including coccolithophores, which are important producers of calcium carbonate in the Mediterranean Sea. This change in seawater $\mathrm{pH}$ also affects the speciation, stoichiometry and the availability of essential nutrients (Hutchins et al. 2009 and references therein, Beman et al. 2011) and, therefore, could have an effect on primary productivity. More acidic conditions are expected to decrease the ammonia concentration at the expense of an increase in ammonium ions (Beman et al. 2011) and slightly reduce phosphate ion concentration (Hutchins et al. 2009). In the Mediterranean, which is generally limited by phosphorous, these changes could accentuate its oligotrophic character and lead to corresponding changes in plankton composition.

All these processes and variables have the potential to interact amongst themselves in different ways, including additive, synergistic or antagonistic interactions. Acidification and warming can act synergistically in worsening the calcification of corals and crustose coralline algae not only in tropical species (Reynaud et al. 2003, Anthony et al. 2008) but also in Mediterranean species (Martin \& Gattuso 2009). Similar to what will probably occur in tropical coral reefs (Anthony et al. 2011), this combination of factors will contribute to reducing the resilience of coralligenous structures, potentially compromising the biodiversity that they contain. Currently, the coralligenous community is especially affected by trawl fishing (causing physical damage and increasing turbidity and sedimentation; Ballesteros 2008) and by introduced algae species (decreasing light availability to encrusting algae, increasing sedimentation, inhibiting recruitment and allowing overgrowth of some species; Ballesteros 2008, Klein \& Verlaque 2008, 2009, Cebrian \& Ballesteros 2009). Simulation studies have shown that mass mortality events driven by climate change dramatically reduce the viability of long-lived and low-turnover structural species of the community when combined with the effects of these additional anthropogenic impacts (Linares et al. 2010). 
The growth, reproduction and formation of jellyfish swarms depend on a set of factors other than those that are strictly climatic. Jellyfish populations benefit from overfishing of commercially valuable fish that feed on the same prey as jellyfish, and overfishing of large carnivorous fish, along with turtles and seabirds, which are natural predators of jelly fish (Purcell et al. 2007). The proliferation of coastal species is also related to the settlement of polyps on artificial structures (Fuentes et al. 2010). This process benefits resident taxa such as Aurelia species, arguably the most widespread blooming jellyfish, and invasive species, such as the cubomedusa Carybdea marsupialis (Bordehore et al. 2011) whose invasion of the Mediterranean Sea is particularly concerning. Fishing is an important driver of structural and functional changes in the ecosystem (Coll et al. 2008) and also alters the demographic structure of fish populations, thereby modifying their ability to respond to climate variability and change (Planque et al. 2010, Hidalgo et al. 2011). Additional anthropogenic pressures are found in water management on land, which affects river discharges (Lloret et al. 2001) and habitat loss and degradation of waters and substrate necessary for fish spawning, feeding and growth (GarcíaRubies \& Macpherson 1995, de Juan \& Lleonart 2010). Disentangling the combined effects of climate change and anthropogenic pressures on fish population dynamics is also of central importance for the understanding of ecosystem functioning, and thus for the management of exploited resources.

\section{MANAGEMENT, MONITORING AND RESEARCH NEEDS}

The most probable directions that changes in the ecosystems of the Catalan Sea will take encompass: (1) the 'meridionalisation' of the biota, which favours the most thermophilic native species and the arrival of foreign species; (2) the reduction of the biodiversity at higher trophic levels; (3) the disappearance of the most fragile and long-lived species with a low turnover, and a reduction in the 3-dimensional biogenic structure; (4) the loss of the capacity to recuperate; (5) the dominance of bottom-up controls in trophic webs in relation to top-down controls; (6) a reduction in the exported production to the sediments or to the trophic levels exploited by humans (Bianchi 2007, CIESM 2008a, Lejeusne et al. 2010).

Environmental assessment and management for mitigating the effects of climate change on marine ecosystems is often based on the idea that the effects are limited in time and the system will be able to recuperate quickly when the environmental pressure stops. Many initiatives aimed at making exploitation of the marine environment sustainable are based on this premise. Unfortunately, it is necessary to highlight the limited success of the tools currently used for managing the exploitation of marine resources. The progressive collapse of the fisheries around the world, for example, questions the supposed reversibility of human impacts in the short and medium term (Pauly \& Watson 2005). In the case of climate change, the supposition of reversibility has been questioned from the beginning, due to the global character of climate change, its inertia (even if the atmospheric composition were held fixed at present values, the climate would continue to change, due to thermal inertia of the sea, Wigley 2005) and the nonlinearity of its effects. Of special concern is that when a threshold is crossed, positive and negative feedbacks could shift ecosystems to a permanent alternative state that no longer functions in the same way as it did in the past (Lenton et al. 2008, Rockström et al. 2009).

Present evidence indicates that global warming is affecting the climate and hydrology of the western Mediterranean Sea and will continue to do so, leading to substantial changes in the composition and dynamics of marine ecosystems. Therefore, in addition to the work necessary for mitigating climate change and adapting to it, we need to take the following action:

(1) Reduce the effect of those disturbing factors we are more able to control (overfishing, destruction of habitats, pollution) and that may act synergistically with climate change to the detriment of marine ecosystems. Some studies aimed at determining the effects associated with climate change, such as the loss of biomass of benthic communities or the expansion of the range of distribution of warmwater species, indicate that the effects of climate change would be attenuated if we were able to reduce the effect of other disturbing factors (Ruiz et al. 2000, Linares et al. 2010). This would give us time to develop a more global action against climate change. However, to distinguish between the effects of climate change and those from other kinds of impacts, it is fundamental to have protected areas that are not affected by other anthropogenic factors that can act as baselines or 'controls'.

(2) Monitor the main physical, chemical and biological variables that are indicators of climate and environmental changes and the speed at which they are occurring. This monitoring should be carried out 
systematically along the coast, but especially in protected areas where, because of management practices and the reduction of other impacting factors, we can discern and assess the effects of climate change. Time series studies, like the one from L'Estartit station and others that are currently underway, are fundamental for the understanding of climate change. The maintenance of these stations, as well as the establishment of new observatories - which could take advantage of initiatives to develop automatic measuring systems in buoys and fixed anchoragesis imperative. The data collected in time series can be used to detect and quantify the effects of climate change, and are vitally important for developing, testing and validating the climate and oceanographic models with which the climate predictions are made.

(3) Investigate the mechanisms and processes through which climate change acts on marine populations. Our capacity to predict the effects of climate change on the ecosystem depend on our degree of understanding of the mechanisms involved. This means that it is necessary to develop imaginative approaches to laboratory experimentation, environmental observation and modelling.

Acknowledgements. We thank Eva Flo and Esther Garcés for constructive comments on an earlier version of the manuscript. E.C., C.P., M.R. and R.C. acknowledge funding from the Spanish Ministerio de Ciencia e Innovación through grants CTM2009-08849/MAR, CTM2006-01463 and CGL2007-66757-C02-01/BOS and a Ramón y Cajal contract to E.C. This paper is a contribution from the Marine Biogeochemistry and Global Change research group, funded by Generalitat de Catalunya (Catalan Government) through grant 2009SGR142.

\section{LITERATURE CITED}

> Agell G, Uriz MJ, Cebrian E, Martí R (2001) Does stress protein induction by copper modify natural toxicity in sponges? Environ Toxicol Chem 20:2588-2593

Anthony KRN, Kline DI, Diaz-Pulido G, Dove S, HoeghGuldberg O (2008) Ocean acidification causes bleaching and productivity loss in coral reef builders. Proc Natl Acad Sci USA 105:17442-17446

Anthony KRN, Maynard JA, Diaz-Pulido G, Mumby PJ, Marshall PA, Cao L, Hoegh-Guldberg O (2011) Ocean acidification and warming will lower coral reef resilience. Glob Change Biol 17:1798-1808

Antonov JI, Levitus S, Boyer TP (2002) Steric sea level variations during 1957-1994: importance of salinity. J Geophys Res 107:8013. doi:8010.1029/2001JC000964

Arai MN (1997) A functional biology of Scyphozoa. Chapman \& Hall, London

Astraldi M, Bianchi CN, Gasparini GP, Morri C (1995) Climatic fluctuations, current variability and marine species distribution: a case study in the Ligurian Sea (north-west Mediterranean). Oceanol Acta 18:139-149

Azzurro E, Andaloro F (2004) A new settled population of the lessepsian migrant Siganus luridus (Pisces: Siganidae) in Linosa Island-Sicily Strait. J Mar Biol Assoc UK 84:819-821

Ballesteros E (2006) Mediterranean coralligenous assemblages: a synthesis of the present knowledge. Oceanogr Mar Biol Annu Rev 44:123-195

Ballesteros E (2008) Plan de acción para la conservación del coralígeno y de las demás bioconcreciones calcáreas del Mediterráneo. Regional Activity Centre for Specially Protected Areas (RAC/SPA), Tunis

Bally M, Garrabou J (2007) Thermodependent bacterial pathogens and mass mortalities in temperate benthic communities: a new case of emerging disease linked to climate change. Glob Change Biol 13:2078-2088

Barange M, Cheung WWL, Merino G, Perry RI (2010) Modelling the potential impacts of climate change and human activities on the sustainability of marine resources. Curr Opin Environ Sustain 2:326-333

Bavestrello G, Bertone S, Cattaneo-Vietti R, Cerrano C, Gaino E, Zanzi D (1994) Mass mortality of Paramuricea clavata (Anthozoa, Cnidaria) on Portofino Promontory cliffs, Ligurian Sea, Mediterranean Sea. Mar Life 4: 15-19

Beaugrand G, Brander KM, Lindley JA, Souissi S, Rei PC (2003) Plankton effect on cod recruitment in the North Sea. Nature 426:661-664

Beman JM, Chow CE, King AL, Feng Y and others (2011) Global declines in oceanic nitrification rates as a consequence of ocean acidification. Proc Nat Acad Sci USA 108:208-213

Ben Rais Lasram F, Mouillot D (2009) Increasing southern invasion enhances congruence between endemic and exotic Mediterranean fish fauna. Biol Invasions 11: 97-711

> Ben Rais Lasram F, Guilhaumon F, Albouy C, Somot S, Thuiller W, Mouillot D (2010) The Mediterranean Sea as a 'cul-de-sac' for endemic fishes facing climate change. Glob Change Biol 16:3233-3245

Bender MA, Knutson TR, Tuleya RE, Sirutis JJ, Vecchi GA, Garner ST, Held IM (2010) Modeled impact of anthropogenic warming on the frequency of intense Atlantic hurricanes. Science 327:454-458

> Beniston M, Stephenson DB, Christensen OB, Ferro CAT and others (2007) Future extreme events in European climate: an exploration of regional climate model projections. Clim Change 81:71-95

> Bensoussan N, Romano JC, Harmelin JG, Garrabou J (2010) High resolution characterization of northwest Mediterranean coastal waters thermal regimes: to better understand responses of benthic communities to climate change. Estuar Coast Shelf Sci 87:431-441

Béthoux JP, Morin P, Ruiz-Pino DP (2002) Temporal trends in nutrient ratios: chemical evidence of Mediterranean ecosystem changes driven by human activity. Deep Sea Res II 49:2007-2016

Béthoux JP, El Boukhary MS, Ruiz-Pino D, Morin P, CopinMontegut C (2005) Nutrient, oxygen and carbon ratios, $\mathrm{CO}_{2}$ sequestration and anthropogenic forcing in the Mediterranean Sea. In: Saliot A (ed) The Mediterranean Sea. The handbook of environmental chemistry, Part 5/5K. Springer, Berlin, p 67-86

Bianchi CN (2007) Biodiversity issues for the forthcoming 
tropical Mediterranean Sea. Hydrobiologia 580:7-21

Bianchi CN, Morri C (2000) Marine biodiversity of the Mediterranean Sea: situation, problems and prospects for future research. Mar Pollut Bull 40:367-376

Bindoff NL, Willebrand J, Artale V, Cazenave A and others (2007) Observations: oceanic climate change and sea level. In: Solomon S, Qin D, Manning M, Chen Z, Marquis $M$, Averyt KB, Tignor M, Miller HL (eds) Climate change 2007: the physical science basis. Contribution of Working Group I to the Fourth Assessment Report of the Intergovernmental Panel on Climate Change. Cambridge University Press, Cambridge, p 385-432

Blanquer A, Uriz MJ (2010) Population genetics at three spatial scales of a rare sponge living in fragmental habitats. BMC Evol Biol 10:13

Bodilis P, Ganteaume A, Francour P (2003) Presence of 1 year-old dusky groupers along the French Mediterranean coast. J Fish Biol 62:242-246

Bombace G (2001) Influence of climatic changes on stocks, fish species and marine ecosystems in the Mediterranean Sea. Arch Oceanogr Limnol 22:67-72

Bordehore C, Fuentes VL, Atienza D, Barberá C and others (2011) Detection of unusual presence of the cubozoan Carybdea marsupialis at shallow beaches located near Denia (SW Mediterranean). Mar Biodivers Rec 4:e69 doi:10.1017/S1755267211000650

> Boyce DG, Lewis MR, Worm B (2010) Global phytoplankton decline over the past century. Nature 466:591-596

Brander K (2010) Impacts of climate change on fisheries. J Mar Syst 79:389-402

> Brodeur RD, Mills CE, Overland JE, Walters GE, Schumacher JD (1999) Evidence for a substantial increase in gelatinous zooplankton in the Bering Sea, with possible links to climate change. Fish Oceanogr 8:296-306

Brodeur RD, Sugisaki H, Hunt GL Jr (2002) Increases in jellyfish biomass in the Bering Sea: implications for the ecosystem. Mar Ecol Prog Ser 233:89-103

$>$ Broecker WS (1979) A revised estimate for the radiocarbon age of North Atlantic Deep Water. J Geophys Res 84: 3218-3226

Broecker WS (1980) Geochemical tracers and ocean circulation. In: Warren BA, Wunsch C (eds) Evolution of physical oceanography. MIT Press, Cambridge, MA, p 434-460

Carreras-Carbonell J, Macpherson E, Pascual M (2006) Population structure within and between subspecies of the Mediterranean triplefin fish Tripterygion delaisi revealed by highly polymorphic microsatellite loci. Mol Ecol 15:3527-3539

Cartes JE, Maynou F, Fanelli E, Papiol V, Lloris D (2009) Long-term changes in the composition and diversity of deep-slope megabenthos and trophic webs off Catalonia (western Mediterranean): Are trends related to climatic oscillations? Prog Oceanogr 82:32-46

Castellón A, Font J, García E (1990) The Liguro-ProvençalCatalan current (Northwestern Mediterranean) observed by Doppler profiling in the Balearic Sea. Sci Mar 54: 269-276

- Cazenave A, Llovel W (2010) Contemporary sea level rise. Annu Rev Mar Sci 2:145-173

> Cebrian E, Ballesteros E (2009) Temporal and spatial variability in shallow- and deep-water populations of the invasive Caulerpa racemosa var. cylindracea in the Western Mediterranean. Estuar Coast Shelf Sci 83:469-474

Cebrian E, Uriz MJ, Garrabou J, Ballesteros E (2011) Sponge mortalities in a warming Mediterranean Sea: Are cyanobacteria-harboring species worse off? PLoS ONE 6:e20211

> Cerrano C, Bavestrello G, Bianchi CN, Cattaneo-Vietti R and others (2000) A catastrophic mass-mortality episode of gorgonians and other organisms in the Ligurian Sea (North-western Mediterranean), summer 1999. Ecol Lett 3:284-293

CIESM (The Mediterranean Science Commission) (2008a) Climate warming and related changes in Mediterranean marine biota. In: Briand F (ed) CIESM workshop monograph 35. CIESM, Monaco

CIESM (2008b) Impacts of acidification on biological, chemical and physical systems in the Mediterranean and Black Seas. In: Briand F (ed) CIESM workshop monograph 36. CIESM, Monaco

CIESM (2009) Dynamics of Mediterranean deep waters. In: Briand F (ed) CIESM workshop monograph 38. CIESM, Monaco

Cigliano M, Gambi MC (2007) The long hot summer: a further mortality event of gorgonians along the Phlaegrean Islands (Tyrrhenian Sea). Biol Mar Mediterr 14:292-293

Coll M, Palomera I, Tudela S, Dowd M (2008) Food-web dynamics in the South Catalan Sea ecosystem (NW Mediterranean) for 1978-2003. Ecol Model 217:95-116

Coll M, Piroddi C, Steenbeek J, Kaschner K and others (2010) The biodiversity of the Mediterranean Sea: estimates, patterns and threats. PLoS ONE 5:e11842

Coma R, Ribes M (2003) Seasonal energetic constraints in Mediterranean benthic suspension feeders: effects at different levels of ecological organization. Oikos 101: 205-215

Coma R, Zabala M (1992) Seguiment temporal de la gorgonia Paramuricea clavata de les illes Medes. Exercici 1992. In: Seguiment temporal de les Illes Medes. Informe anual 1992. Departament d'Agricultura, Ramaderia i Pesca, Generalitat de Catalunya, Barcelona

Coma R, Ribes M, Gili JM, Zabala M (1998) An energetic approach to the study of life-history traits of two modular benthic invertebrates. Mar Ecol Prog Ser 162:89-103

Coma R, Linares C, Ribes M, Diaz D, Garrabou J, Ballesteros E (2006) Consequences of a mass mortality in populations of Eunicella singularis (Cnidaria: Octocorallia) in Menorca (NW Mediterranean). Mar Ecol Prog Ser 327: 51-60

Coma R, Serrano E, Linares C, Ribes M, Calvin JC (2007) Informe sobre el estado de la poblaciones de gorgonias de la reserva marina de las Islas Hormigas. Servicio de Pesca y Acuicultura de la Comunidad Autónoma de Murcia, Cartagena

Coma R, Ribes M, Serrano E, Jiménez E, Salat J, Pascual J (2009) Global warming-enhanced stratification and mass mortality events in the Mediterranean. Proc Natl Acad Sci USA 106:6176-6181

> Coma R, Serrano E, Linares C, Ribes M, Díaz D, Ballesteros E (2011) Sea urchins predation facilitates coral invasion in a marine reserve. PLoS ONE 6:e22017

> Company JB, Puig P, Sardà F, Palanques A, Latasa M, Scharek R (2008) Climate control on deep-sea fisheries. PLoS ONE 3:e1431. doi:10.1371/journal.pone.0001431

> Conversi A, Fonda Umani S, Peluso T, Molinero JC and others (2010) The Mediterranean Sea regime shift at the end of the 1980s, and intriguing parallelisms with other European basins. PLoS ONE 5:e10633

> Corriero G, Sara M, Vaccaro P (1996) Sexual and asexual 
reproduction in two species of Tethya (Porifera: Demospongiae) from a Mediterranean coastal lagoon. Mar Biol 126:175-181

Cupido R, Cocito S, Barsanti M, Sgorbini S, Peirano A, Santangelo G (2009) Unexpected long-term population dynamics in canopy-forming gorgonian coral following mass mortality. Mar Ecol Prog Ser 394:195-200

Daniel B, Piro S, Charbonnel E, Francour P, Letourneur Y (2009) Lessepsian rabbitfish Siganus luridus reached the French Mediterranean coasts. Cybium 33:163-164

> Danovaro R, Dinet A, Duineveld G, Tselepides A (1999) Benthic response to particulate fluxes in different trophic environments: a comparison between the Gulf of LionCatalan Sea (western-Mediterranean) and the Cretan Sea (eastern-Mediterranean). Prog Oceanogr 44:287-312

de Juan S, Lleonart J (2010) A conceptual framework for the protection of vulnerable habitats impacted by fishing activities in the Mediterranean high seas. Ocean Coast Manag 53:717-723

Doney SC, Fabry VJ, Feely RA, Kleypas JA (2009) Ocean acidification: the other $\mathrm{CO}_{2}$ problem. Annu Rev Mar Sci 1:169-192

> Duarte CM, Agustí S, Kennedy H, Vaqué D (1999) The Mediterranean climate as a template for Mediterranean marine ecosystems: the example of the northeast Spanish littoral. Prog Oceanogr 44:245-270

> Dulçic J, Pallaoro A (2004) First record of the marbled spinefoot Siganus rivulatus (Pisces: Siganidae) in the Adriatic Sea. J Mar Biol Assoc UK 84:1087-1088

> Duran S, Pascual M, Estoup A, Turon X (2004) Strong population structure in the marine sponge Crambe crambe (Poecilosclerida) as revealed by microsatellite markers. Mol Ecol 13:511-522

Estrada M, Margalef R (1988) Supply of nutrients to the Mediterranean photic zone along a persistent front. Oceanol Acta 9:133-142

Fabry VJ, Seibel BA, Feely RA, Orr JC (2008) Impacts of ocean acidification on marine fauna and ecosystem processes. ICES J Mar Sci 65:414-432

Falkowski PG, Barber RT, Smetacek V (1998) Biogeochemical controls and feedbacks on ocean primary production. Science 281:200-207

> Fernández de Puelles ML, Molinero JC (2008) Decadal changes in hydrographic and ecological time-series in the Balearic Sea (western Mediterranean), identifying links between climate and zooplankton. ICES J Mar Sci 65:311-317

> Font J (1990) A comparison of seasonal winds with currents on the continental slope of the Catalan Sea (Northwestern Mediterranean). J Geophys Res 95:1537-1545

Font J, Salat J, Tintoré J (1988) Permanent features of the circulation in the Catalan Sea. Oceanol Acta S9:51-57

> Francour P, Boudouresque CF, Harmelin JG, HarmelinVivien ML, Quignard JP (1994) Are the Mediterranean waters becoming warmer? Information from biological indicators. Mar Pollut Bull 28:523-526

Fuentes V, Atienza D, Gili JM, Purcell JE (2009) First records of Mnemiopsis leidyi A. Agassiz 1865 off the NW Mediterranean. Aquat Invasions 4:671-674

Fuentes VL, Angel DL, Bayha KM, Atienza D and others (2010) Blooms of the invasive ctenophore, Mnemiopsis leidyi, span the Mediterranean Sea in 2009. Hydrobiologia 645:23-37

Fuentes V, Straehler-Pohl I, Atienza D, Franco I and others (2011) Life cycle of the jellyfish Rhizostoma pulmo
(Scyphozoa: Rhizostomeae) and its distribution, seasonality and inter-annual variability along the Catalan coast and the Mar Menor (Spain, NW Mediterranean). Mar Biol 158:2247-2266

Gaino E, Pronzato R (1989) Ultrastructural evidence of bacterial damage to Spongia officinalis fibres (Porifera, Demospongiae). Dis Aquat Org 6:67-74

Gaino E, Pronzato R, Corriero G, Buffa P (1992) Mortality of commercial sponges: incidence in two Mediterranean areas. Boll Zool 59:79-85

Galarza JA, Carreras-Carbonell J, Macpherson E, Pascual M, Roques S, Turner GF, Rico C (2009) The influence of oceanographic fronts and early life-history traits on connectivity among littoral fish species. Proc Natl Acad Sci USA 106:1473-1478

Gambaiani DD, Mayol P, Isaac SJ, Simmonds MP (2009) Potential impacts of climate change and greenhouse gas emissions on Mediterranean marine ecosystems and cetaceans. J Mar Biol Assoc UK 89:179-201

Gambi MC, Cigliano M, Iacono B (2006) Segnalazione di un evento di mortalità di Gorgonacei lungo le coste delle isole di Ischia e Procida (Golfo di Napoli, Mar Tirreno). Biol Mar Mediterr 13:583-587

García-Rubies A, Macpherson E (1995) Substrate use and temporal pattern of recruitment in juvenile fishes on the Mediterranean littoral. Mar Biol 124:35-42

> Garrabou J, Perez T, Sartoreto S, Harmelin JG (2001) Mass mortality event in red coral (Corallium rubrum, Cnidaria, Anthozoa, Octocorallia) populations in Provence region (France, NW Mediterranean). Mar Ecol Prog Ser 217: 263-272

> Garrabou J, Ballesteros E, Zabala M (2002) Structure and dynamics of north-western Mediterranean rocky benthic communities along a depth gradient. Estuar Coast Shelf Sci 55:493-508

> Garrabou J, Coma R, Bensoussan N, Bally M and others (2009) Mass mortality in Northwestern Mediterranean rocky benthic communities: effects of the 2003 heat wave. Glob Change Biol 15:1090-1103

Gili JM, Fuentes V, Atienza D, Lewinsky I (2010) Report of the Medusa Project. Tech Rep No. 8. Agencia Catalana de l'Aïgua, Generalitat de Catalunya, Barcelona

Goffart A, Hecq JH, Legendre L (2002) Changes in the development of the winter-spring phytoplankton bloom in the Bay of Calvi (NW Mediterranean) over the last two decades: a response to changing climate? Mar Ecol Prog Ser 236:45-60

Gomis D, Ruiz S, Sotillo MG, Álvarez-Fanjul E, Terradas J (2008) Low frequency Mediterranean sea level variability: the contribution of atmospheric pressure and wind. Glob Planet Change 63:215-229

> Goy J, Morand P, Etienne M (1989) Long-term fluctuations of Pelagia noctiluca (Cnidaria, Scyphomedusa) in the western Mediterranean Sea. Prediction by climatic variables. Deep-Sea Res 36:269-279

> Guadayol O, Peters F, Marrase C, Gasol JM and others (2009) Episodic meteorological and nutrient-load events as drivers of coastal planktonic ecosystem dynamics: a time-series analysis. Mar Ecol Prog Ser 381:139-155

> Guinotte JM, Fabry VJ (2008) Ocean acidification and its potential effects on marine ecosystems. Ann NY Acad Sci 1134:320-342

Harmelin JG (1984) Biologie du corail rouge. Paramètres de populations, croissance et mortalité naturelle. Etat des connaissances en France. FAO Fish Rep 306:99-103 
Harvell CD, Kim K, Burkholder JM, Colwell RR and others (1999) Emerging marine diseases-climate links and anthtopogenic factors. Science 285:1505-1510

Harvell CD, Mitchell CE, Ward JR, Altizer S, Dobson AP, Ostfeld RS, Samuel MD (2002) Climate warming and disease risks for terrestrial and marine biota. Science 296:2158-2162

> Hawkins SJ, Southward AJ, Genner NJ (2003) Detection of environmental change in a marine ecosystem-evidence from the western English Channel. Sci Total Environ 310:245-256

> Hidalgo M, Rouyer T, Molinero JC, Massutí E, Moranta J, Guijarro B, Stenseth NC (2011) Synergistic effects of fishing-induced demographic changes and climate variation on fish population dynamics. Mar Ecol Prog Ser 426:1-12

Hoegh-Guldberg O, Bruno JF (2010) The impact of climate change on the world's marine ecosystems. Science 328: 1523-1528

Hutchins DA, Mulholland MR, Fu F (2009) Nutrient cycles and marine microbes in a $\mathrm{CO}_{2}$-enriched ocean. Oceanography 22:128-145

Kawasaki T (1992) Mechanisms governing fluctuations in pelagic fish populations. In: Payne AIL, Brink KH, Mann $\mathrm{KH}$, Hilborn R (eds) Benguela trophic functioning. S Afr J Mar Sci 12:873-879

Kersting DK, García-March JR, Templado J (2006) Evaluation of Spondylus gaederopus Linneo, 1758 mass mortality event in the Columbretes Islands Marine Reserve (Western Mediterranean, Spain). International Congress on Bivalvia. Universitat Autònoma de Barcelona, Bellaterra

Klein J, Verlaque M (2008) The Caulerpa racemosa invasion: a critical review. Mar Pollut Bull 56:205-225

Klein JC, Verlaque M (2009) Macroalgal assemblages of disturbed coastal detritic bottoms subject to invasive species. Estuar Coast Shelf Sci 82:461-468

Krom MD, Kress N, Brenner S, Gorden LI (1991) Phosphorous limitation of primary production in the eastern Mediterranean Sea. Limnol Oceanogr 36:424-432

> Lambeck K, Anzidei M, Antonioli F, Benini A, Esposito A (2004) Sea level in Roman time in the Central Mediterranean and implications for recent change. Earth Planet Sci Lett 224:563-575

Learmonth JA, MacLeod CD, Santos MB, Pierce GJ, Crick HQP, Robinson RA (2006) Potential effects of climate change on marine mammals. Oceanogr Mar Biol Annu Rev 44:431-464

Ledoux JB, Mokhtar-Jamaï K, Roby C, Féral JP, Garrabou J, Aurelle D (2010) Genetic survey of shallow populations of the Mediterranean red coral [Corallium rubrum (Linnaeus, 1758)]: new insights into evolutionary processes shaping nuclear diversity and implication for conservation. Mol Ecol 19:675-690

Lejeusne C, Chevaldonné P (2006) Brooding crustaceans in a highly fragmented habitat: the genetic structure of Mediterranean marine cave-dwelling mysid populations. Mol Ecol 15:4123-4140

Lejeusne C, Chevaldonné P, Pergent-Martini C, Boudouresque $C F$, Pérez $T$ (2010) Climate change effects on a miniature ocean: the highly diverse, highly impacted Mediterranean Sea. Trends Ecol Evol 25:250-260

Lenton TM, Held H, Kriegler E, Hall JW, Lucht W, Rahmstorf S, Schellnhuber HJ (2008) Tipping elements in the Earth's climate system. Proc Natl Acad Sci USA 105: 1786-1793
Linares C, Coma R, Diaz D, Zabala M, Hereu B, Dantart L (2005) Immediate and delayed effects of a mass mortality event on gorgonian population dynamics and benthic community structure in the NW Mediterranean Sea. Mar Ecol Prog Ser 305:127-137

Linares C, Coma R, Diaz D, Garrabou J, Zabala M (2008a) Size distribution, density and disturbance in two Mediterranean gorgonians: Paramuricea clavata and Eunicella singularis. J Appl Ecol 45:688-699

> Linares C, Coma R, Zabala M (2008b) Effects of a mass mortality event on reproduction of the gorgonian Paramuricea clavata. Coral Reefs 27:27-34

Linares C, Zabala M, Garrabou J, Coma R and others (2010) Assessing the impact of diving in coralligenous communities: the usefulness of demographic studies of red gorgonian populations of long-lived gorgonians. Sci Rep Port-Cros Natl Park 24:161-184

> Lionello P, Cogo S, Galati MB, Sanna A (2008) The Mediterranean surface wave climate inferred from future scenario simulations. Glob Planet Change 63:152-162

Lleonart J, Maynou F (2003) Fish stock assessments in the Mediterranean: state of the art. Sci Mar 67(Suppl): $37-49$

Lloret J, Lleonart J, Sole I, Fromentin JM (2001) Fluctuations of landings and environmental conditions in the northwestern Mediterranean Sea. Fish Oceanogr 10:33-50

Lloret J, Palomera I, Salat J, Solé I (2004) Impact of freshwater input and wind on landings of anchovy (Engraulis encrasicolus) and sardine (Sardina pilchardus) in shelf waters surrounding the Ebre (Ebro) River delta (northwestern Mediterranean). Fish Oceanogr 13:102-110

Lluch-Belda D, Crawford RJM, Kawasaki T, MacCall AD, Parrish RH, Schwartzlose RA, Smith PE (1989) Worldwide fluctuations of sardine and anchovy stocks: the regime problem. S Afr J Mar Sci 8:195-205

> López-Bustins JA, Martin-Vide J, Sanchez-Lorenzo A (2008) Iberia winter rainfall trends based upon changes in teleconnection and circulation patterns. Glob Planet Change 63:171-176

> López-Moreno JI, Beniston M (2009) Daily precipitation intensity projected for the 21st century: seasonal changes over the Pyrenees. Theor Appl Climatol 95:375-384

> Luczak C, Beaugrand G, Jaffré M, Lenoir S (2011) Climate change impact on Balearic shearwater through a trophic cascade. Biol Lett 7:702-705

Lynam CP, Heath MR, Hay SJ, Brierley AS (2005) Evidence for impacts by jellyfish on North Sea herring recruitment. Mar Ecol Prog Ser 298:157-167

Magnuson JJ, Crowder LB, Medvick PA (1979) Temperature as an ecological resource. Am Zool 19:331-343

> Maldonado M, Sánchez-Tocino L, Navarro C (2010) Recurrent disease outbreaks in corneous demosponges of the genus Ircinia: epidemic incidence and defense mechanisms. Mar Biol 157:1577-1590

- Marcos M, Tsimplis MN (2008) Coastal sea level trends in Southern Europe. Geophys J Int 175:70-82

Margalef R (1964) Fitoplancton de las costas de Blanes (provincia de Gerona, Mediterráneo Occidental), de julio de 1959 a junio de 1963. Inv + Pesq 26:131-164

Margalef R (1978) Life-forms of phytoplankton as survival alternatives in an unstable environment. Oceanol Acta 1:493-509

> Martin S, Gattuso JP (2009) Response of Mediterranean coralline algae to ocean acidification and elevated temperature. Glob Change Biol 15:2089-2100 
Martin Y, Bonnefont JL, Chancerelle L (2002) Gorgonians mass mortality during the 1999 late summer in French Mediterranean coastal waters: the bacterial hypothesis. Water Res 36:779-782

> Martín P, Bahamon N, Sabatés A, Maynou F, Sánchez P, Demestre M (2008) European anchovy (Engraulis encrasicolus) landings and environmental conditions on the Catalan Coast (NW Mediterranean) during 2000-2005. Hydrobiologia 612:185-199

Martín P, Sabatés A, Lloret J, Martin-Vide J (2011) Climate modulation of fish populations: the role of the Western Mediterranean Oscillation (WeMO) in sardine (Sardina pilchardus) and anchovy (Engraulis encrasicolus) production in the north-western Mediterranean. Clim Change doi:10.1007/s10584-011-0091-z

Martin-Vide J, Lopez-Bustins JA (2006) The Western Mediterranean oscillation and rainfall in the Iberian peninsula. Int J Climatol 26:1455-1475

Marty JC, Chiavérini J (2010) Hydrological changes in the Ligurian Sea (NW Mediterranean, DYFAMED site) during 1995-2007 and biogeochemical consequences. Biogeosciences $7: 2117-2128$

Marty JC, Chiavérini J, Pizay MD, Avril B (2002) Seasonal and interannual dynamics of nutrients and phytoplankton pigments in the western Mediterranean Sea at the DYFAMED time-series station (1991-1999). Deep-Sea Res II 49:1965-1985

> Massutí E, Monserrat S, Oliver P, Moranta J and others (2008) The influence of oceanographic scenarios on the population dynamics of demersal resources in the western Mediterranean: hypothesis for hake and red shrimp off Balearic Islands. J Mar Syst 71:421-438

- Maynou F (2008) Environmental causes of the fluctuations of red shrimp (Aristeus antennatus) landings in the Catalan Sea. J Mar Syst 71:294-302

Meehl GA, Stocker TF, Collins WD, Friedlingstein P and others (2007) Global climate projections. In: Solomon S, Qin D, Manning M, Chen Z and others (eds) Climate change 2007: the physical science basis. Contribution of Working Group I to the Fourth Assessment Report of the Intergovernmental Panel on Climate Change. Cambridge University Press, Cambridge, p 747-845

Millot C, Taupier-Letage I (2005) Circulation in the Mediterranean Sea. In: Saliot A (ed) The Mediterranean Sea. The handbook of environmental chemistry, Part 5/5K. Springer, Berlin, p 323-334

Mills CE (2001) Jellyfish blooms: Are populations increasing globally in response to changing ocean conditions? Hydrobiologia 451:55-68

Mistri M, Ceccherelli VU (1996) Effects of a mucilage event on the Mediterranean gorgonian Paramuricea clavata. I. Short term impacts at the population and colony levels. Ital J Zool 63:221-230

Mokhtar-Jamaï K, Pasqual M, Ledoux JB, Coma R, Féral JP, Garrabou J, Aurelle D (2011) From global to local genetic structuring in the red gorgonian Paramuricea clavata: the interplay between oceanographic conditions and limited larval dispersal. Mol Ecol 20:3291-3305

Molinero JC, Ibanez F, Souissi S, Chiffet M, Nival P (2005) Phenological changes in the northwestern Mediterranean copepods Centrophages typicus and Temora stylifera linked to climate forcing. Oecologia 145:640-649

Molinero JC, Casini M, Buecher E (2008a) The influence of the Atlantic and regional climate variability on the longterm changes in gelatinous carnivore populations in the northwestern Mediterranean. Limnol Oceanogr 53: 1456-1467

Molinero JC, Ibanez F, Souissi S, Buercher E, Dallot S, Nival P (2008b) Climate control on the long-term anomalous changes of zooplankton communities in the Northwestern Mediterranean. Glob Change Biol 14:11-26

Mosso C, Mestres M, Sierra JP, Sanchez-Arcilla A, Goodess C (2009) Waves and surges in the Valencia Gulf. Variability rather than climate change. J Coast Res SI56: 243-247

Mozeti P, Solidoro C, Cossarini G, Socal G and others (2010) Recent trends towards oligotrophication of the Northern Adriatic: evidence from chlorophyll a time series. Estuar Coast 33:362-375

Ninčević Gladan Ž, Marasovi I, Grbec B, Skeji S and others (2010) Inter-decadal variability in phytoplankton community in the middle Adriatic (Kaštela Bay) in relation to the North Atlantic Oscillation. Estuar Coast 33:376-383

Nykjaer L (2009) Mediterranean Sea surface warming 1985-2006. Clim Res 39:11-17

Ospina-Álvarez N, Piferrer F (2008) Temperature-dependent sex determination in fish revisited: prevalence, a single sex ratio response pattern, and possible effects of climate change. PLoS ONE 3:e2837

> Palomera I, Olivar MP, Salat J, Sabatés A, Coll M, García A, Morales-Nin B (2007) Small pelagic fish in the NW Mediterranean Sea: an ecological review. Prog Oceanogr 74:377-396

Patarnello T, Volckaert FAMJ, Castilho R (2007) Pillars of Hercules: Is the Atlantic-Mediterranean transition a phylogeographical break? Mol Ecol 16:4426-4444

> Pauly D, Watson R (2005) Background and interpretation of the 'Marine Trophic Index' as a measure of biodiversity. Philos Trans R Soc Lond B Biol Sci 360:415-423

> Pauly D, Christensen V, Dalsgaard J, Froese R, Torres F Jr (1998) Fishing down marine food webs. Science 279: 860-863

> Pelejero C, Calvo E, Hoegh-Guldberg O (2010) Paleoperspectives on ocean acidification. Trends Ecol Evol 25:332-344

Perez T, Garrabou J, Sartoretto S, Harmelin JG, Francour P, Vacelet J (2000) Mass mortality of marine invertebrates: an unprecedented event in the Northwestern Mediterranean. C R Acad Sci Serie III Sci Vie 323:853-865

> Perry RI, Ommer RE, Barange M, Werner F (2010) The challenge of adapting marine social-ecological systems to the additional stress of climate change. Curr Opin Environ Sustain 2:356-363

Petchey OL, McPhearson PT, Casey TM, Morin PJ (1999) Environmental warming alters food-web structure and ecosystem function. Nature 402:69-72

Planque B, Fromentin JM, Cury P, Drinkwater KF, Jennings S, Perry RI, Kifani S (2010) How does fishing alter marine populations and ecosystems sensitivity to climate? J Mar Syst 79:403-417

> Polovina JJ, Howell EA, Abecassis M (2008) Ocean's least productive waters are expanding. Geophys Res Lett 35:L03618. doi:10.1029/2007GL031745

Purcell JE, Arai MN (2001) Interactions of pelagic cnidarians and ctenophores with fish: a review. Hydrobiologia 451: $27-44$

> Purcell JE, Grover JJ (1990) Predation and food limitation as causes of mortality in larval herring at a spawning ground in British Columbia. Mar Ecol Prog Ser 59:55-67 Purcell JE, Uye S, Lo WT (2007) Anthropogenic causes of 
jellyfish blooms and their direct consequences for humans: a review. Mar Ecol Prog Ser 350:153-174

Quignard JP, Raibault A (1993) Ichthyofauna of the Languedocian coast (Gulf of Lion). Faunistic and demographic modifications. Vie Milieu 43:191-195

Rahmstorf S (2007) A semi-empirical approach to projecting future sea-level rise. Science 315:368-370

Raitsos DE, Beaugrand G, Georgopoulos D, Zenetos A, Pancucci-Papadopoulou AM, Theocharis A, Papathanassiou E (2010) Global climate change amplifies the entry of tropical species into the Eastern Mediterranean Sea. Limnol Oceanogr 55:1478-1484

Raven JA, Caldeira K, Elderfield H, Hoegh-Guldberg O and others (2005) Ocean acidification due to increasing atmospheric carbon dioxide. Policy document 12/05. The Society, London

Reynaud S, Leclercq N, Romaine-Lioud S, Ferrier-Pages C, Jaubert J, Gattuso JP (2003) Interacting effects of $\mathrm{CO}_{2}$ partial pressure and temperature on photosynthesis and calcification in a scleractinian coral. Glob Change Biol 9:1660-1668

Riera F, Grau AM, Pastor E, Pou S (1995) Faunistical and demographical observations in Balearic ichthyofauna. In: La Méditerranée: variabilités climatiques, environnement et biodiversité. Actes Colloque scientifique OKEANOS, Montpellier, p 213-220

Rixen M, Beckers JM, Levitus S, Antonov J and others (2005) The Western Mediterranean Deep Water: a proxy for climate change. Geophys Res Lett 32:L12608 doi:10. 1029/2005GL022702

Rockström J, Steffen W, Noone K, Persson A and others (2009) A safe operating space for humanity. Nature 461: $472-475$

Rodolfo Metalpa R, Bianchi CN, Peirano A, Morri C (2000) Coral mortality in NW Mediterranean. Coral Reefs 19:24

- Rodolfo-Metalpa R, Bianchi CN, Peirano A, Morri C (2005) Tissue necrosis and mortality of the temperate coral Cladocora caespitosa. Ital J Zool 72:271-276

Romano JC, Bensoussan N, Younes WAN, Arlhac D (2000) Anomalies thermiques dans les eaux du golfe de Marseille durant l'été 1999. Une explication partielle de la mortalité d'invertébrés fixés. C R Acad Sci Serie III Sci Vie 323:415-427

Ros J (2009) El mar i les costes catalanes ja noten l'efecte del canvi climàtic. A Aigua i Canvi Climàtic. Diagnosi dels impactes previstos a Catalunya. Agència Catalana de l'Aigua, Generalitat de Catalunya, Barcelona, p 259-277

> Rossi S, Sabatés A, Latasa M, Reyes E (2006) Lipid biomarkers and trophic linkages between phytoplankton, zooplankton and anchovy (Engraulis encrasicolus) larvae in the NW Mediterranean. J Plankton Res 28:551-562

Ruiz GM, Fofonoff PW, Carlson JT, Wonham MJ, Hines AH (2000) Invasion of coastal marine communities in North America: apparent patterns, processes, and biases. Annu Rev Ecol Syst 31:481-531

Sabatés A, Martin P, Lloret J, Raya V (2006) Sea warming and fish distribution: the case of the small pelagic fish, Sardinella aurita, in the western Mediterranean. Glob Change Biol 12:2209-2219

Sabatés A, Salat J, Raya V, Emelianov M, Segura-Noguera M (2009) Spawning environmental conditions of Sardinella aurita at the northern limit of its distribution range, the western Mediterranean. Mar Ecol Prog Ser 385:227-236

Sabatés A, Pagès F, Atienza D, Fuentes V, Purcell JE, Gili JM (2010) Planktonic cnidarian distribution and feeding of Pelagia noctiluca from near shore to open sea in the NW Mediterranean. Hydrobiologia 645:153-165

Sabine CL, Feely RA, Gruber N, Key RM and others (2004) The oceanic sink for anthropogenic $\mathrm{CO}_{2}$. Science 305: 367-371

Salat J, Pascual J (2002) The oceanographic and meteorological station at l'Estartit (NW Mediterranean). In: Briand F (ed) Tracking long-term hydrological change in the Mediterranean Sea. CIESM Workshop Ser 16, CIESM, Monaco

Salat J, Pascual J (2006) Principales tendencias climatológicas en el Mediterráneo Noroccidental, a partir de más de 30 años de observaciones oceanográficas y meteorológicas en la costa catalana. In: Cuadrat Prats JM, Saz Sánchez MA, Vicente Serrano SM, Lanjeri S, de Luis Arrillaga M, González-Hidalgo JC (eds) Clima, sociedad y medio ambiente. Publicaciones de la Sociedad Española de Climatología, Zaragoza

Salen-Picard C, Darnaude A, Arlhac D, Harmelin-Vivien ML (2002) Fluctuations of macrobenthic populations: a link between climate-driven run-off and sole fishery yields in the Gulf of Lions. Oecologia 133:380-388

Sánchez-Arcilla A, González-Marco D, Bolaños R (2008) A review of wave climate and prediction along the Spanish Mediterranean coast. Nat Hazards Earth Syst Sci 8: 1217-1228

Sarmiento JL, Hughes TMC, Stouffer RJ, Manage S (1998) Simulated response of the ocean carbon cycle to anthropogenic climate warming. Nature 393:245-249

Scharek R, Latasa M, Massana R, Balagué V (2007) Comparing microphytoplankton seasonality after 50 years at a coastal site in the northwest Mediterranean. In: Effects of climate change on the world's oceans. PICES Secretariat, Sydney

Siapatis A, Giannoulaki M, Valavanis VD, Palialexis A, Schismenou E, Machias A, Somarakis S (2008) Modelling potential habitat of the invasive ctenophore Mnemiopsis leidyi in Aegean Sea. Hydrobiologia 612:281-295

Sivan D, Lambeck K, Toueg R, Raban A, Porath Y, Shirman B (2004) Ancient coastal wells of Caesarea Maritima, Israel, an indicator for relative sea level changes during the last 2000 years. Earth Planet Sci Lett 222:315-330

Solic M, Krstulovic N, Marasovic I, Baranovic A, PucherPetkovic T, Vucetic T (1997) Analysis of time series of planktonic communities in the Adriatic Sea: distinguishing between natural and man-induced changes. Oceanol Acta 20:131-143

> Steinacher M, Joos F, Frölicher TL, Plattner GK, Doney SC (2009) Imminent ocean acidification in the Arctic projected with the NCAR global coupled carbon cycleclimate model. Biogeosciences 6:515-533

Stephens JS, Hose JH, Love MS (1988) Fish assemblages as indicators of environmental change in nearshore environment. In: Soule DF, Keppel GS (eds) Marine organisms as indicators. Springer, New York, NY, p 91-103

Stige LC, Ottersen G, Dalpadado P, Chan KS, Hjermann DØ, Lajus DL, Yaragina NA, Stenseth NC (2010) Direct and indirect climate forcing in a multi-species marine system. Proc R Soc B Biol Sci 277:3411-3420

Supić N, Grbec B, Vilibic I, Ivancic I (2004) Long-term changes in hydrographic conditions in northern Adriatic and its relationship to hydrological and atmospheric processes. Ann Geophys 22:733-745

Thomas OP, Sarrazin V, Ivanisevic J, Amade P, Pérez T (2007) Sponge chemical defenses in stress conditions: the 
case study of the last disease outbreak observed in the NW Mediterranean. 5th Eur Conf Mar Nat Products, Ischia, Italy, p 61

Torrents O, Tambutté E, Caminiti N, Garrabou J (2008) Upper thermal thresholds of shallow vs. deep populations of the precious Mediterranean red coral Corallium rubrum (L.): assessing the potential effects of warming in the NW Mediterranean. J Exp Mar Biol Ecol 357:7-19

Touratier F, Goyet C (2009) Decadal evolution of anthropogenic $\mathrm{CO}_{2}$ in the northwestern Mediterranean Sea from the mid-1990s to the mid-2000s. Deep-Sea Res I 56:1708-1716

Touratier F, Goyet C (2011) Impact of the Eastern Mediterranean Transient on the distribution of anthropogenic $\mathrm{CO}_{2}$ and first estimate of acidification for the Mediterranean Sea. Deep-Sea Res I 58:1-15

Trenberth KE, Jones PD, Ambenje P, Bojariu R and others (2007) Observations: surface and atmospheric climate change. In: Solomon S, Qin D, Manning M, Chen Z and others (eds) Climate change 2007: the physical science basis. Contribution of Working Group I to the Fourth Assessment Report of the Intergovernmental Panel on Climate Change. Cambridge University Press, Cambridge, p 235-336

Tsimplis MN, Josey SA (2001) Forcing of the Mediterranean Sea by atmospheric oscillations over the North Atlantic. Geophys Res Lett 28:803-806

Turley CM, Bianchi M, Christaki U, Conan P and others (2000) Relationship between primary producers and bacteria in an oligotrophic sea: the Mediterranean and biogeochemical implications. Mar Ecol Prog Ser 193: 11-18

Vargas-Yáñez M, García Martínez MC, Moya Ruiz F, Tel E and others (2007) Cambio climático en el Mediterráneo español. Instituto Español de Oceanografía, Madrid

- Vargas-Yáñez M, Jesús García M, Salat J, García-Martínez MC, Pascual J, Moya F (2008) Warming trends and decadal variability in the Western Mediterranean shelf. Glob Planet Change 63:177-184
Vargas-Yáñez M, Moya F, Garcia-Martinez MC, Tel E and others (2010) Climate change in the Western Mediterranean Sea 1900-2008. J Mar Syst 82:171-176

Vázquez-Domínguez E, Vaque D, Gasol AM (2007) Ocean warming enhances respiration and carbon demand of coastal microbial plankton. Glob Change Biol 13: $1327-1334$

Vázquez-Rodríguez M, Touratier F, Lo Monaco C, Waugh DW and others (2009) Anthropogenic carbon distributions in the Atlantic Ocean: data-based estimates from the Arctic to the Antarctic. Biogeosciences 6:439-451

Vezulli L, Previati M, Pruzzo C, Marchese A, Gourne DG, Cerrano C, and the VibrioSea Consortium (2010) Vibrio infections triggering mass mortality events in a warming Mediterranean Sea. Environ Microb 12:2007-2019

Vives F, Suau P (1956) El espadín del Mediterráneo occidental (Clupea sprattus var. phalerica Risso). Inv Pesq 4:3-24

- Wigley TML (2005) The climate change commitment. Science 307:1766-1769

> Worm B, Barbier EB, Beaumont N, Duffy JE and others (2006) Impacts of biodiversity loss on ocean ecosystem services. Science 314:787-790

> Wynn RB, Josey SA, Martin AP, Johns DG, Yésou P (2007) Climate-driven range expansion of a critically endangered top predator in northeast Atlantic waters. Biol Lett 3:529-532

Zabala M, Louisy P, García-Rubies A, Gracia V (1997) Sociobehavioral context of the reproduction in the Mediterranean dusky grouper Epinephelus marginatus (Lowe, 1834) (Pisces, Serranidae) in the Medes Islands Marine Reserve (NW Mediterranean, Spain). Sci Mar 61:79-98

$>$ Zavodnik D (1987) Spatial aggregations of the swarming jellyfish Pelagia noctiluca (Scyphozoa). Mar Biol 94: 265-269

> Zeebe RE, Zachos JC, Caldeira K, Tyrrell T (2008) Carbon emissions and acidification. Science 321:51-52

Zingone A, Dubroca L, Iudicone D, Margiotta F and others (2010) Coastal phytoplankton do not rest in winter. Estuar Coast 33:342-361 


\section{Appendix 1. Climate change effects}

Table A1. Summary of the effects of climate change on marine organisms

\begin{tabular}{|c|c|c|c|}
\hline Organisms & Documented effects & Likely related cause or causes & Source \\
\hline \multicolumn{4}{|c|}{ Planktonic primary producers and heterotrophs } \\
\hline \multicolumn{4}{|l|}{ Phytoplankton } \\
\hline Coastal assemblages & Decrease in overall biomass & $\begin{array}{l}\text { Reduced eutrophication in the } \\
\text { last decade }\end{array}$ & $\begin{array}{l}\text { Mozeti et al. (2010), } \\
\text { Ninčević Gladan et al. (2010) }\end{array}$ \\
\hline $\begin{array}{l}\text { Open sea assemblages in } \\
\text { strongly stratified waters }\end{array}$ & Decrease in overall biomass & $\begin{array}{l}\text { Longer lasting and stronger water } \\
\text { column stratification }\end{array}$ & Goffart et al. (2002) \\
\hline $\begin{array}{l}\text { Open sea assemblages in } \\
\text { strongly mixed waters }\end{array}$ & $\begin{array}{l}\text { Increase in overall biomass, } \\
\text { shift to smaller taxa }\end{array}$ & Earlier water column stratification & Marty et al. (2002) \\
\hline \multicolumn{4}{|l|}{ Zooplankton } \\
\hline \multirow[t]{2}{*}{ Copepods } & $\begin{array}{l}\text { Changes in local species } \\
\text { composition }\end{array}$ & $\mathrm{NAO}$ & Molinero et al. (2005) \\
\hline & $\begin{array}{l}\text { Substitution of copepods by } \\
\text { gelatinous zooplankton }\end{array}$ & High NAO & Molinero et al. (2008b) \\
\hline Bacterioplankton & Limited and inconclusive data & & Duarte et al. (1999) \\
\hline \multicolumn{4}{|l|}{ Jellyfish on the coast } \\
\hline Pelagia noctiluca & Increase in the frequency & Seawater temperature increase, & Gili et al. (2010) \\
\hline Rhizostoma pulmo & and number of swarms & overfishing, human recreation & \\
\hline Physalia physalis & & activities & \\
\hline \multicolumn{4}{|l|}{ Cotylorhiza tuberculata } \\
\hline \multicolumn{4}{|l|}{ Aurelia aurita } \\
\hline \multicolumn{4}{|l|}{ Velella velella } \\
\hline \multicolumn{4}{|l|}{ Olindias phosphorica } \\
\hline \multicolumn{4}{|l|}{ Aequorea forskalea } \\
\hline \multicolumn{4}{|l|}{ Phyllorhiza punnctata } \\
\hline \multicolumn{4}{|l|}{ Chrysaora hysoscella } \\
\hline \multicolumn{4}{|l|}{ Porpita porits } \\
\hline \multirow{2}{*}{\multicolumn{4}{|c|}{$\begin{array}{l}\text { Carybdea marsupials } \\
\text { Ctenophora }\end{array}$}} \\
\hline & & & \\
\hline Mnemiopsis leiyi & $\begin{array}{l}\text { Increase in the frequency } \\
\text { and number of swarms }\end{array}$ & $\begin{array}{l}\text { Seawater temperature increase, } \\
\text { overfishing }\end{array}$ & Gili et al. (2010) \\
\hline \multicolumn{4}{|l|}{ Coralligenous community } \\
\hline \multicolumn{4}{|l|}{ Cnidaria } \\
\hline Paramuricea clavata & $\begin{array}{l}\text { Decrease in gonadal output } \\
\text { of colonies }\end{array}$ & $\begin{array}{l}\text { Extent of partial mortality, } \\
\text { temperature and stratification } \\
\text { increase }\end{array}$ & Linares et al. (2008b) \\
\hline Paramuricea clavata & Large increase in partial and & Seawater temperature, stratification & Cerrano et al. (2000), \\
\hline Eunicella cavolinii & total mortality & increase & Perez et al. (2000), \\
\hline Eunicella sigularis & & & Linares et al. (2005), \\
\hline Eunicella verrucosa & & & Coma et al. $(2006,2009)$, \\
\hline Leptogorgia sarmentosa & & & Garrabou et al. (2009) \\
\hline \multicolumn{4}{|l|}{ Corallium rubrum } \\
\hline \multicolumn{4}{|l|}{ Cladocora caespitosa } \\
\hline \multicolumn{4}{|l|}{ Balanophyllia italica } \\
\hline \multirow{2}{*}{\multicolumn{4}{|c|}{$\begin{array}{l}\text { Oculina patagonica } \\
\text { Parazoanthus axinellae }\end{array}$}} \\
\hline & & & \\
\hline Porifera & & & \\
\hline Spongia officinalis & Large increase in partial and & Seawater temperature, & Gaino et al. (1992), \\
\hline Ircinia dendroides & total mortality & stratification increase/disease & Coma \& Ribes (2003), \\
\hline Ircinia variabilis & & & Maldonado et al. (2010), \\
\hline Ircinia oros & & & Cebrian et al. (2011) \\
\hline Agelas oroides & & & \\
\hline Crambe crambe & & & \\
\hline Cacospongia spp. & & & \\
\hline Hippospongia communis & & & \\
\hline Petrosia ficiformis & & & \\
\hline Spongia agaricina & & & \\
\hline Clathrina clathrus & & & \\
\hline Aplysina cavernícolas & & & \\
\hline Reniera fulva & & & \\
\hline
\end{tabular}




\begin{tabular}{|c|c|c|c|}
\hline Organisms & Documented effects & Likely related cause or causes & Source \\
\hline \multicolumn{4}{|l|}{ Bryozoa } \\
\hline Myriapora truncata & \multirow{5}{*}{$\begin{array}{l}\text { Large increase in partial and } \\
\text { total mortality }\end{array}$} & \multirow{5}{*}{$\begin{array}{l}\text { Thermal anomaly, latent water- } \\
\text { borne agent }\end{array}$} & \multirow{5}{*}{$\begin{array}{l}\text { Perez et al. (2000), } \\
\text { Garrabou et al. (2009) }\end{array}$} \\
\hline Adeonella calveti & & & \\
\hline Turbicellepora aviculari & & & \\
\hline Pentapora fascialis & & & \\
\hline Bivalvia & & & \\
\hline Spondylus gaederopus & \multirow{7}{*}{ Large increase in total mortality } & \multirow{7}{*}{$\begin{array}{l}\text { Climatic anomaly; } \\
\text { infection by microorganisms }\end{array}$} & \multirow{7}{*}{$\begin{array}{l}\text { Perez et al. (2000), } \\
\text { Garrabou et al. (2009) }\end{array}$} \\
\hline Lima spp. & & & \\
\hline Arca spp. & & & \\
\hline Ostrea edulis & & & \\
\hline Lithophaga lithophaga & & & \\
\hline Neopycnodonte cochlear & & & \\
\hline Ascidiacea & & & \\
\hline Microcosmus spp. & \multirow{3}{*}{ Large increase in total mortality } & \multirow{3}{*}{$\begin{array}{l}\text { Climatic anomaly; } \\
\text { infection by microorganisms }\end{array}$} & \multirow[t]{3}{*}{ Perez et al. (2000) } \\
\hline Halocynthia papillosa & & & \\
\hline Pyura dura & & & \\
\hline \multirow{2}{*}{\multicolumn{4}{|c|}{ Fish and fisheries }} \\
\hline & & & \\
\hline Thalassoma pavo & \multirow{5}{*}{ Northward range extension } & \multirow[t]{5}{*}{ Seawater temperature increase } & \multirow{4}{*}{$\begin{array}{l}\text { Francour et al. (1994), } \\
\text { Sabatés et al. (2006) }\end{array}$} \\
\hline Xyrichtys novacula & & & \\
\hline Pomatomus saltatrix & & & \\
\hline Pomadasys incisus & & & \\
\hline \multicolumn{2}{|l|}{ Sardinella aurita } & & \\
\hline Epinephelus marginatus & Enhancing reproduction & $\begin{array}{l}\text { Seawater temperature increase, } \\
\text { Marine Protected Area } \\
\text { establishment }\end{array}$ & Zabala et al. (1997) \\
\hline Sardinella aurita & $\begin{array}{l}\text { Enhancing reproduction and } \\
\text { recruitment }\end{array}$ & Seawater temperature increase & $\begin{array}{l}\text { Sabatés et al. (2006), } \\
\text { (2009) }\end{array}$ \\
\hline Engraulis encrasicolus & Low catches & $\begin{array}{l}\text { River runoff decrease, sea water } \\
\text { temperature increase, low WeMO }\end{array}$ & $\begin{array}{l}\text { Lloret et al. (2004), } \\
\text { Palomera et al. (2007), } \\
\text { Martín et al. (2008), } \\
\text { Martín et al. (2011) }\end{array}$ \\
\hline Sardina pilchardus & Low catches & $\begin{array}{l}\text { River runoff decrease, sea water } \\
\text { temperature increase, wind } \\
\text { mixing decrease/ low WeMO }\end{array}$ & $\begin{array}{l}\text { Lloret et al. (2004), } \\
\text { Palomera et al. (2007), } \\
\text { Martín et al. (2011) }\end{array}$ \\
\hline Solea solea & Low catches & River runoff decrease & Salen-Picard et al. (2002) \\
\hline Merluccius merluccius & High recruitment & Low or negative NAO & Massutí et al. (2008) \\
\hline Crustaceans & & & \\
\hline Aristeus antennatus & $\begin{array}{l}\text { High catches, high spawning } \\
\text { stock and abundance }\end{array}$ & Positive and high NAO and MO & $\begin{array}{l}\text { Maynou (2008), } \\
\text { Massutí et al. (2008) }\end{array}$ \\
\hline Aristeus antennatus & Variability in catches & Shelf water cascading events & Company et al. (2008) \\
\hline
\end{tabular}

Editorial responsibility: Geir Ottersen, Oslo, Norway
Submitted: December 1, 2010; Accepted: August 8, 2011

Proofs received from author(s): November 9, 2011 